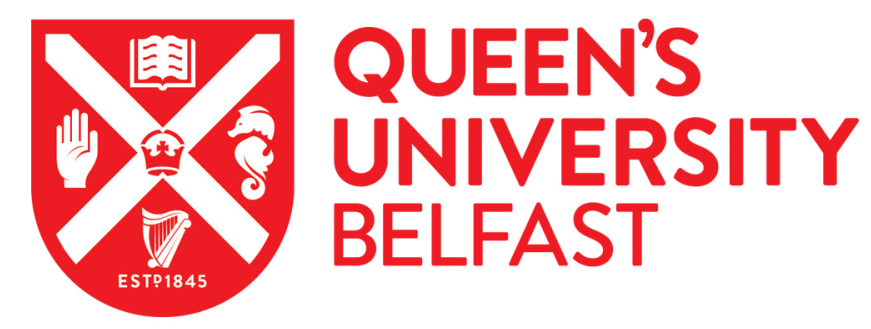

\title{
Prosecutions, imprisonment and the Stormont House Agreement: a critical analysis of proposals on dealing with the past in Northern
} Ireland

McEvoy, K., Holder, D., Mallinder, L., Bryson, A., Gormally, B., \& McKeown, G. (2020). Prosecutions,

imprisonment and the Stormont House Agreement: a critical analysis of proposals on dealing with the past in Northern Ireland. QUB Human Rights Centre. https://s3-eu-west-

1.amazonaws.com/caj.org.uk/2020/04/09093700/Prosecutions-Imprisonment-the-SHA-LOW-RES.pdf

Document Version:

Publisher's PDF, also known as Version of record

Queen's University Belfast - Research Portal:

Link to publication record in Queen's University Belfast Research Portal

Publisher rights

(C) 2020 Committee on the Administration of Justice.

This work is made available online in accordance with the publisher's policies. Please refer to any applicable terms of use of the publisher.

\section{General rights}

Copyright for the publications made accessible via the Queen's University Belfast Research Portal is retained by the author(s) and / or other copyright owners and it is a condition of accessing these publications that users recognise and abide by the legal requirements associated with these rights.

Take down policy

The Research Portal is Queen's institutional repository that provides access to Queen's research output. Every effort has been made to ensure that content in the Research Portal does not infringe any person's rights, or applicable UK laws. If you discover content in the Research Portal that you believe breaches copyright or violates any law, please contact openaccess@qub.ac.uk. 


\section{PROSECUTIONS, IMPRISONMENT AND THE STORMONT HOUSE AGREEMENT}

\section{A Critical Analysis Of Proposals On Dealing With The Past In Northern Ireland}
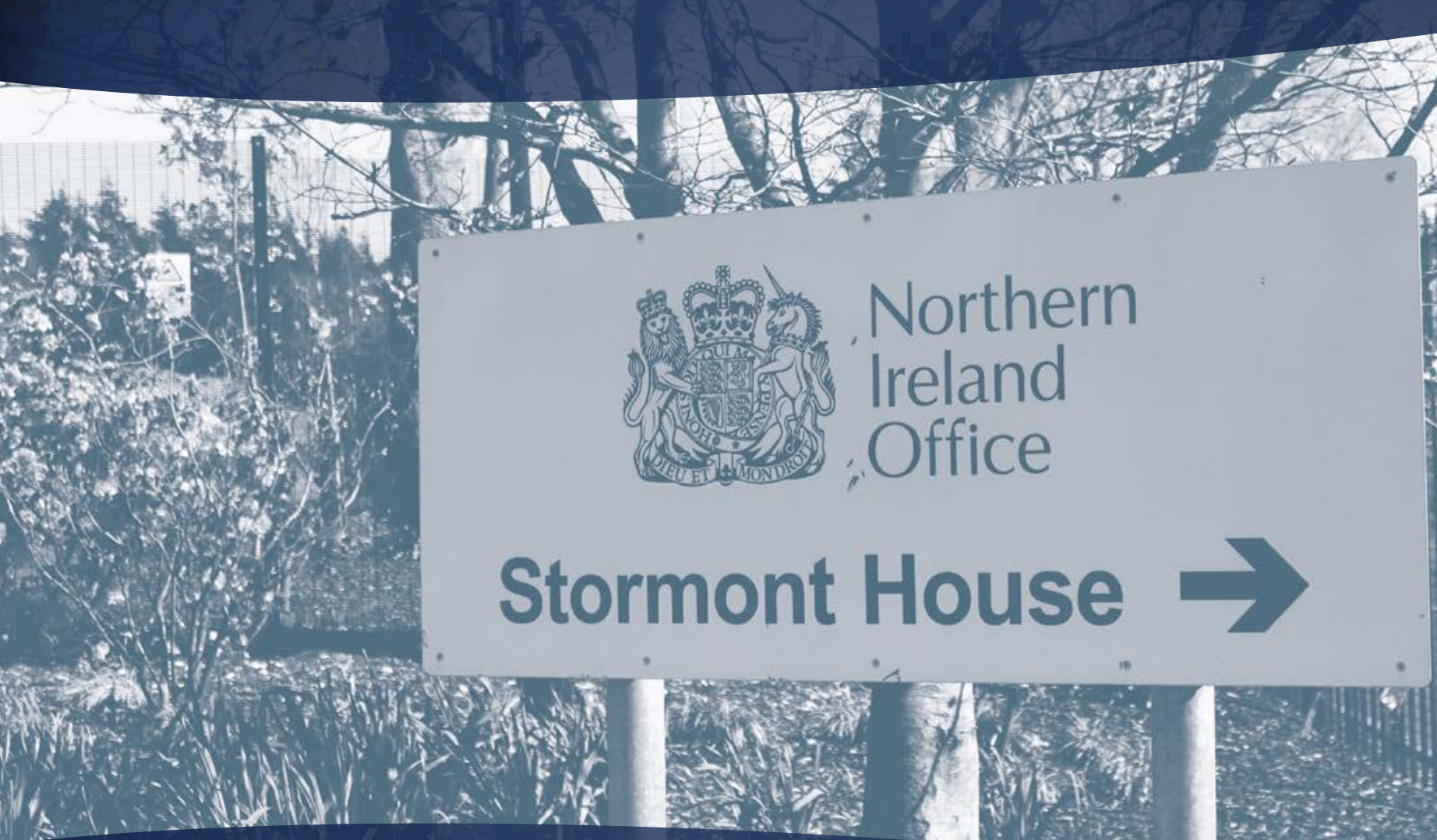

Stormont House

in in:

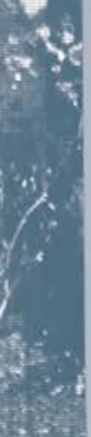

4 .

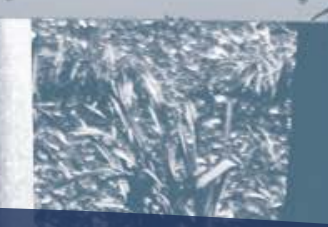

Kieran McEvoy, Daniel Holder,

Louise Mallinder, Anna Bryson, Brian Gormally \& Gemma McKeown 


\section{PROSECUTIONS, IMPRISONMENT AND THE STORMONT HOUSE AGREEMENT:}

\section{A Critical Analysis of Proposals on Dealing with the Past in Northern Ireland}

\section{Contents}

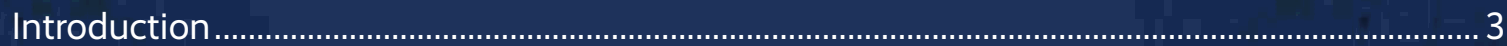

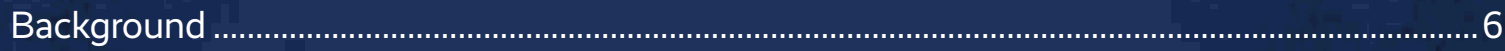

The Stormont House Agreement ...................................................................................................... 6

Understanding the 'Witch-Hunt' Narrative: Conflict-Related Investigations,

Prosecutions and Imprisonment ............................................................................................. 8

An 'Imbalanced Approach' To Legacy Investigations And Prosecutions ............................ 9

'The Early Release Scheme Only Benefitted Paramilitaries'................................................ 11

The 'On The Run' Scheme was an 'Amnesty for Paramilitaries' ......................................12

Vexatious Litigation and the European Convention on Human Rights ...........................13

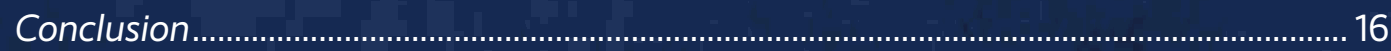

Proposal 1: Implement The Stormont House Agreement ............................................................17

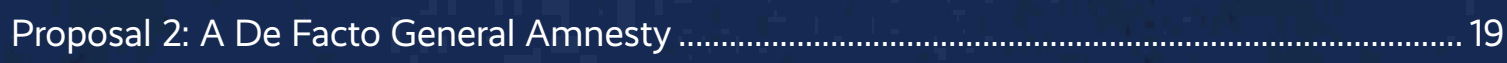

Proposal 3: A Statute Of Limitations For The Security Forces ....................................................... 20

Proposal 4: Prosecutions Of Soldiers Requiring Consent Of The Attorney

General For England And Wales .

Proposal 5: Prosecution Decisions Based On Whether The Weapon

Was 'Lawfully Supplied'.

Proposal 6: Power To Veto Prosecutions By The AGNI, A 'Commissioner'

Or A 'Senior Judge'..

Proposal 7: A Legacy Commission As An Alternative To Prosecution .......................................... 30

Proposal 8: The March 2020 Northern Ireland Office Proposal ...................................................32

Proposal 9: The Innocent Victims United 'LIB To Replace HIU Proposal' ..................................36

Proposal 10: Implement The SHA, Reduce Conflict-Related Imprisonment

From Two Years To Zero, Based On Cooperation With The ICIR .................................................... 41

Proposal 11: Implement The SHA, Reduce Conflict-Related Imprisonment

To Zero With No ICIR Cooperation Requirement ..........................................................................47

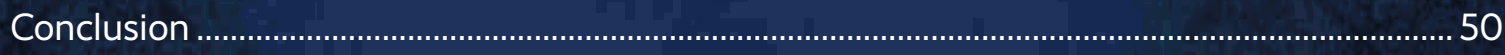




\section{Introduction $^{1}$}

In January 2020, the United Kingdom government committed to introducing legislation to implement the legacy aspects of the Stormont House Agreement (SHA) within 100 days as part of the agreement to re-establish the Northern Ireland Executive. ${ }^{2}$ The government also committed to engaging with the local political parties and the Irish government in 'an intensive process' to 'maintain a broad-based consensus on these issues'. However, in March 2020 the government appeared to shift its position quite dramatically. That change in position was explicitly prompted by the introduction of a Bill to set a presumptive five-year time limit on prosecutions for members of the UK armed forces who have served overseas. ${ }^{3}$ In response, in a Written Ministerial Statement to the House of Commons, the Secretary of State for Northern Ireland, Brandon Lewis MP, said that the government proposed to address legacy '...ensuring equal treatment of Northern Ireland veterans and those who served overseas.' ${ }^{4}$ The statement went on to claim that '.... while the principles underpinning the draft Bill as consulted on in 2018 remain, significant changes will be needed to obtain a broad consensus for the implementation of any legislation. ${ }^{.5}$ There has been little to indicate that any consensus had been built by the UK government in support of this sudden change in policy.

This report is designed to offer a contribution to the ongoing deliberations of the UK and Irish governments, the local political parties, and civil society on dealing with the legacy of the past in Northern Ireland. All of the options and proposals discussed below are benchmarked against three key tests.

a. The extent to which it is consistent with binding domestic and international human rights obligations, in particular Article 2 of the European Convention on Human Rights regarding the right to an effective investigation into conflict-related deaths. ${ }^{6}$

b. The extent to which it is compatible with the Good Friday Agreement (GFA), the cornerstone of the Northern Ireland peace process.

c. The extent to which it is compatible with the Stormont House Agreement. Although the design of that (SHA) is complex, it was arrived at after months of tortuous

1 This report was prepared by the 'Model Bill Team' based at Queen's University Belfast and the Committee on the Administration of Justice, Belfast. The team consists of Professor Kieran McEvoy, Professor Louise Mallinder and Dr Anna Bryson (all Queen's University Belfast, School of Law) and Daniel Holder, Brian Gormally and Gemma McKeown (all Committee on the Administration of Justice). Since 2013, this team has produced a range of technical briefings and reports designed to help inform public debates on dealing with the past. Members of the team have also given written and oral evidence to the US Congress (2015), the Westminster Defence Select Committee (2017), the Dáil Joint Oireachtas Committee on the Implementation of the Good Friday Agreement (2018) and the Westminster Northern Ireland Affairs Committee (2019). See further https://www.dealingwiththepastni.com/.

2 Northern Ireland Office (2020) New Decade, New Approach p. 48.

3 Overseas Operations (Service Personnel and Veterans) Bill (HC Bill 117) First Reading, 18th March 2020.

4 Hansard House of Commons Written Ministerial Statement, 8th March 2020 Vol 673, 168.

5 Stormont House Agreement (2014) Paragraph 21. 'As part of the transition to long-term peace and stability the participants agree that an approach to dealing with the past is necessary which respects the following principles: promoting reconciliation; upholding the rule of law; acknowledging and addressing the suffering of victims and survivors; facilitating the pursuit of justice and information recovery; is human rights compliant; and is balanced, proportionate, transparent, fair and equitable.'

6 NOTE ON TERMINOLOGY As ever in the Northern Ireland context, disputes on terminology can arise. Our focus herein is on providing accessible legal and policy analysis, using clear and unambiguous terms to help readers make up their own mind on these complex and sensitive matters. The conflict, sometimes referred to as the Troubles, refers to actions concerning the constitutional status of Northern Ireland by republican paramilitaries, loyalist paramilitaries, the security forces (in Northern Ireland and the Republic of Ireland) and others from 1966 onwards. 
negotiations between the two governments and the five largest political parties, and it remains the closest we have come to a workable consensus on dealing with the legacy of the past since the GFA of 1998.

We have previously produced detailed reports on the information recovery and oral history elements of the proposed SHA mechanisms. ${ }^{7}$ This report also contains reflections on information recovery - in particular with regard to obligations under Article 2 of the European Convention on Human Rights (ECHR) to conduct an effective investigation. In addition, because of its particular prominence in a number of the proposals discussed below, we focus on the theme of conflict-related prosecutions and imprisonment.

As is detailed below, when the Stormont House Agreement was concluded in 2014, it included provisions for conflict-related investigations and prosecutions. In fact, for a number of the parties involved in such negotiations, such a 'justice option' was often described as a 'red line' issue. That said, given the evidential difficulties in prosecuting historical cases, all of the parties were aware that realistically there was never likely to be a large number of successful prosecutions arising from legacy investigations. As has been evidenced by the work of the existing legacy facing investigations and prosecutions to date, such an assessment was warranted.

In the absence of the establishment of the Stormont House Agreement mechanisms, the Police Service of Northern Ireland, the Historical Enquiries Team (HET) (until 2014), specialist outside police investigations (e.g. the Operation Kenova investigation into Stakeknife) and the Police Ombudsman have all been involved in legacy-related investigations. Following investigation, the decision on whether or not to prosecute in a legacy case is made by the Public Prosecution Service. ${ }^{8}$

According to information provided by the Director of Public Prosecutions (DPP), since January 2012, 33 cases have been passed by investigators to the DPP for decisions on whether or not to prosecute. $^{9}$

- The DPP has initiated legacy prosecutions in 17 cases, deciding not to prosecute in 16 cases.

- Eight of the cases that went forward to prosecution were against alleged republican paramilitaries, 4 against alleged loyalists and 5 against British Army personnel (6 soldiers in total, one case involves two soldiers).

7 The Model Bill Team (2016) Stormont House Agreement: Model Implementation Bill; The Model Bill Team (2016) Clause by Clause: The Reasoning in the Stormont House Agreement 'Model Bill' on Dealing with the Past in Northern Ireland; The Model Bill Team (2017) Proposed Model for Information Redaction under the Stormont House Agreement; The Model Bill Team (2018) Addressing the Legacy of Northern Ireland's Past: Response to the NIO Public Consultation.

8 The prosecutorial test used by the PPS is an evidential one - whether there is sufficient evidence to offer a 'reasonable prospect of a conviction' and whether it is in the public interest that a decision to prosecute can be taken. The public interest test is that there is broadly an assumption that it is in the public interest to prosecute when there has been a contravention of the criminal law. Issues which are considered include the seriousness of the offence, whether the suspect was in a position of authority or trust and the offence was an abuse of that authority, whether the offence involved a firearm or other weapon, whether the offence was committed against a person serving the public e.g. the police. See further Public Prosecution Service (2016) Code for Prosecutors at p. 16-19.

9 Letter from Director of Public Prosecutions to Professor Kieran McEvoy, 10th January 2020. As discussed further below, under the terms of the Northern Ireland Sentences Act 1998, anyone who is convicted of a conflict-related offence after 1973 and who meets the criteria for eligibility for early release, will only serve a maximum of two years, regardless the length of sentence given by the court. 
- Nine cases are currently before the courts (2 suspected republicans, 2 suspected loyalists and 5 British Army personnel).

- Since 2012, 4 prosecutions have resulted in convictions - 2 republicans and 2 loyalists.

Despite the very small number of conflict-related prosecutions that are likely to result in a conviction, this issue has dominated much of the discussions on legacy in Britain. We have argued previously that the best way to address the legacy of the past in Northern Ireland is to implement the SHA mechanisms in good faith, maximise their independence and appoint good staff to ensure that they deliver on the promises made to victims. ${ }^{10}$ That remains our position.

However, given the prominence of the public focus on the issue of historical prosecutions over British Army veterans in particular, we decided to review all of the proposals put into the public domain by legislators, legal officers and other key stakeholders and to benchmark them against commitments made in the Good Friday Agreement, the Stormont House Agreement, and relevant human rights standards. We also assess their practical workability insofar as possible.

This report provides:

1. A brief background to the SHA mechanisms and the political debates associated with legacy-related prosecutions and imprisonment for conflict-related offences.

2. A critique of the 'witch-hunt' narrative concerning legacy-focused investigations and prosecutions of former soldiers.

3. An overview and assessment of the various proposals that have been suggested to address the concerns noted above. 


\section{Background}

The implementation of the December 2014 Stormont House Agreement has been long delayed. In 2018, the UK government finally published the Draft Northern Ireland (Stormont House Agreement) Bill and began a public consultation on its contents. ${ }^{11}$ In May 2019 the government published an analysis of more than 17,000 responses received. ${ }^{12}$ Although a statute of limitations was not formally included as a theme in the consultation, a clear majority of all respondents to the consultation argued that a statute of limitations or amnesty would not be appropriate for Troubles-related matters (discussed further below). ${ }^{13}$ In the December 2019 Queen's Speech, the government committed to 'seek the prompt implementation of the Stormont House Agreement in order to provide both reconciliation for victims and greater certainty for military veterans' ${ }^{\text {'14 }}$ The Queen's Speech also stated that, 'in parallel with the Stormont House Agreement institutions we will tackle the inappropriate application of the Human Rights Act to issues that occurred before it came into force.'15 In January 2020, the United Kingdom government committed to introduce legislation to implement the SHA within 100 days. ${ }^{16}$ Finally, as noted above, in March 2020 the government appeared to alter its position away from implementing the SHA towards one described as 'sticking to the principles of the SHA' but 'shifting the focus of our approach to the past. ${ }^{\text {.17 }}$

In order to better understand the context for the proposals reviewed below, the following section offers some relevant background on the contents of the SHA itself as well as key themes in what is often described as the 'witch-hunt narrative' i.e. allegations that the existing legacy mechanisms and indeed the SHA are imbalanced.

\section{The Stormont House Agreement}

While there were a range of 'past facing' elements contained in the Good Friday Agreement (1998) (including provisions for support for victims and the early release of prisoners convicted of conflict-related offences) ${ }_{1}^{18}$ the Agreement contained no overarching mechanism such as a Truth and Reconciliation Commission to comprehensively 'deal with the past'. In the intervening years, in part to meet legal obligations under the ECHR and also to honour commitments made in negotiations during the peace process, a 'package of measures' or 'piecemeal' approach to the past in Northern Ireland emerged. ${ }^{9}$ This has included:

public inquiries into controversial events; ${ }^{20}$

- the work of the Office of the Police Ombudsman (OPONI, investigating allegations of historical police malfeasance); ${ }^{21}$

19 As a result of the UK having been found to have been in breach of its human rights obligations under the ECHR in a number of important Northern Ireland conflict-related judgments (often referred to as 'the McKerr group of cases') the government have repeatedly cited the package of measures (including the SHA) as its way of addressing those legal obligations. See e.g. CAJ (March 2020) Submission to the Committee of Ministers in Relation to the Supervision of the Cases Concerning the Action of the Security Forces in Northern Ireland (January 2020). See also K. McEvoy (2013) Dealing with the Past? An Overview of Legal and Political Approaches Relating to the Conflict in and about Northern Ireland; United Nation (2016) Report of the Special Rapporteur on the Promotion of Truth, Justice, Reparation and Guarantees of Non-Recurrence on his Mission to the United Kingdom of Great Britain and Northern Ireland.

20 See e.g. The Report of the Bloody Sunday Inquiry [Saville Report], HC 29-I - HC 29-X, Volumes 1-10 (HMSO, 2010).

21 For an overview see https://www.policeombudsman.org/. 
- coronial inquests into conflict-related deaths; ${ }^{22}$

- police-led investigations and reviews under first the Historical Enquiries Team and now the Police Service of Northern Ireland (PSNI) Legacy Investigation Branch (LIB); ${ }^{23}$

- further litigation by affected families in the domestic courts and the European Court of Human Rights. ${ }^{24}$

This piecemeal approach is universally recognised as inadequate, not only because it fails both to address the needs of victims and promote reconciliation but also because it is perceived by some to focus disproportionate attention on the role of state actors in the conflict. After lengthy negotiations, in 2014, the British and Irish governments and the five main political parties in Northern Ireland agreed to create four mechanisms to deal with legacy the past. These are the:

Historical Investigations Unit (HIU): An independent investigative institution to take over the past-focused work previously undertaken by the HET and OPONI. It will have the equivalent powers of the PSNI to arrest, stop, search, question, retain evidence and so forth. Under the terms of the SHA, the HIU is required to carry out investigations in a manner which is compatible with Article 2 of the ECHR (e.g. initiated by the state, independent, effective, prompt, transparent, with family participation and capable of leading to a prosecution). The HIU is required to produce a report for the affected families in the case of each of the deaths that it investigates..$^{25}$ The Director of Public Prosecutions shall make the decision as to whether the threshold has been met to initiate a prosecution. Anyone convicted of a conflict-related offence committed after 1973 will serve a maximum of two years under the terms of the Good Friday Agreement (discussed further below). ${ }^{26}$

Independent Commission on Information Retrieval (ICIR): An independent international body established by treaty by the UK and Irish governments. The function of this body is to allow victims and survivors to seek and privately receive information about the circumstances surrounding the Troubles-related death of their next of kin. Where an individual requests information through this process, the ICIR will seek to engage with those who may have knowledge of their relative's death. In order to facilitate those with such information coming forward, the SHA specifies that no information provided can be used for criminal or civil proceedings. ${ }^{27}$ In addition, there are guarantees that the process would operate confidentially and the ICIR would not make public, nor disclose to families, the names of persons who provide information nor persons identified as being responsible for the deaths.

22 N. Murphy (2016) Inquests and the Failure by the State to Discharge its International Legal Obligations and Comply with the Lord Chief Justice's Concept Plan.

23 HMIC (2013) Inspection of the Police Service of Northern Ireland Historical Enquiries Team; HMIC (2015) A follow-up Inspection of the Police Service of Northern Ireland Historical Enquiries Team.

24 See G. Anthony and L. Moffett, 'Northern Ireland Law, Politics and the "Problem of the Past"' (2014) 20(3) European Public Law 395-406.

25 The Stormont House Agreement (2014) para 30 <www.gov.uk/government/publications/the-stormont-house-agreement> accessed 10 February 2016.

26 Schedule 18 of the Draft SHA Bill includes a provision to move backwards the applicability of the early release scheme established under the Northern Ireland Sentences Act to cover offences committed between 1st January 1968 and 8th August 1973. This would remove the anomaly that currently exists wherein those convicted for offences before August 1973 are liable to serve their full sentence whereas those convicted afterwards would only serve a maximum of two years.

27 ibid para 41-50. 
Oral History Archive (OHA): is designed to provide a central place where people from all backgrounds (and from throughout the UK and Ireland) could share experiences and narratives related to the Troubles. The SHA noted that, as well as collecting new material, the $\mathrm{OHA}$ will attempt to 'draw together and work with existing oral history projects'. The SHA also stipulated that the OHA will be 'independent and free from political interference.'. ${ }^{28}$

Implementation and Reconciliation Group (IRG): This body will be established to oversee themes, archives and information recovery. Under the terms of the SHA, the IRG will commission a report on themes from 'independent academic experts'. The evidence base for patterns and themes will be referred to the IRG from any of the other legacy mechanisms. The IRG was envisaged in the SHA as consisting primarily of political nominees, with the DUP appointing three members, Sinn Féin two, and the other parties which were signatories to the Agreement appointing one each, as would the two governments - with an independent chair of international standing appointed by First Minister and Deputy First Minister. The work of the IRG is designed to 'promote reconciliation' and a 'better understanding of the past' and to 'reduce sectarianism.' In the context of that work, the UK and Irish governments will consider 'statements of acknowledgement' and 'would expect others to do the same.29

\section{Understanding the 'Witch-Hunt' Narrative: Conflict-Related Investigations, Prosecutions and Imprisonment}

As is detailed below, whilst the Good Friday Agreement had provisions for the early release of those convicted of conflict-related offences, it did not contain an amnesty stipulating that there would be no further prosecutions for such offences. Similarly, during the negotiations that led to the Stormont House Agreement in 2014, none of the five Northern Ireland political parties or indeed the British or Irish government argued in favour of an amnesty. As noted above, all of those involved in the negotiations supported a 'justice option' i.e. police-led investigations with the possibility of prosecutions if the prosecutorial test was met.

Regardless of that political consensus to continue conflict-related investigations and prosecutions, a narrative has nonetheless emerged (in Britain in particular) to suggest that inquests, investigations and prosecutions constitute a 'witch-hunt' directed specifically against former members of the British security forces and in particular British soldiers. Although we do not dismiss the political consequences of such a narrative - indeed this paper is designed to help provide solutions to precisely the political issues raised - it is important to address directly the factual and legal inaccuracies upon which this argument is constructed.

Having reviewed the relevant parliamentary debates and media commentary, we have below extracted some of the key elements of the 'witch-hunt' narrative and then tried to address them with relevant legal and factual data. 


\section{An 'Imbalanced Approach' to Legacy Investigations and Prosecutions}

The 'witch-hunt' narrative is frequently underpinned by an argument that police legacy investigations are disproportionately focused on former soldiers. ${ }^{30}$ While it was operational, the PSNI report that the Historical Enquiries Team completed 1,615 cases - 1,038 were attributed to republican paramilitaries, 566 to loyalists and 32 to the security forces ( 9 were of unknown attribution). ${ }^{31}$ In 2017, the Legacy Investigation Branch of the PSNI (which replaced the HET) stated that of its caseload of 923 Troubles-related cases, 379 were attributed to republicans, 230 to loyalists, 282 to the security forces ( 238 military and 44 police) and 31 unknown. ${ }^{32}$

Given that the state was directly responsible for at least 360 or $10 \%$ of the overall fatalities of the conflict (leaving aside the issue of collusion), ${ }^{33}$ the fact that almost one third of the cases under investigation by the LIB are state focused has been suggested as evidence that such investigations are imbalanced. ${ }^{34}$

However, the reason for such a comparatively high number of state-involved investigations is that it has been accepted by the PSNI that many state-killings were not properly investigated in the first place. For example, in the period between 1970 and 1973, an RUC Force Order was in place which meant that police officers investigating a death caused by a solider did not interview the soldier in question - that task was conducted by the Royal Military Police (RMP) rather than the investigating detectives. This practice was strongly criticised by the former Lord Chief Justice of Northern Ireland, and was ultimately stopped at the insistence of the then newly appointed DPP for Northern Ireland Sir Basil Shaw, himself a former soldier. ${ }^{35}$ As one former senior army officer responsible for criminal investigations and litigation against

30 BBC News Northern Ireland 9th December 2016, 'Troubles Killings: Police Deny Soldier 'Witch-hunt.'

31 Legacy Investigative Branch PSNI (2017) Written evidence of Submitted to the Defence Select Committee.

32 Ibid. Updated figures provided by PSNI as at February 2020 regarding former HET cases are 383 republican, 230 loyalist, 238 Military, 44 Police and 32 Unknown.

33 By definition, it is difficult to be precise about the number of conflict-related deaths which involved the collusion of state actors and the nature and extent of that collusion in the absence of an over-arching truth recovery process. However, from existing sources we already know the following: the Glenanne gang (involving loyalists, UDR and RUC officers) committed over 120 murders; the Police Ombudsman investigations into Operation Ballast involved 10 murders and 6 murders in North Belfast and Loughinisland respectively, finding collusion in both cases; the de Silva report, quoting an internal Security Service review, reports that, between 1985 and 1989, 85\% of UDA "intelligence" originated from the security forces; Lord Stevens, who conducted three investigations into collusion, arrested 210 loyalists as part of his investigation - of these, 207 were informers; Operation Kenova is currently investigating over 40 murders linked to the alleged agent Stakeknife, focusing on the IRA, members of the British Army, the security services and other government agencies. See further A. Cadwallader (2013) Lethal Allies: British Collusion in Ireland; OPONI (2007) Operation Ballast: Investigation into the Circumstances Surrounding the Murder of Raymond McCord Jr; OPONI (2016) The Murders at the Heights Bar in Loughinisland; Desmond de Silva (2012) The Report of the Patrick Finucane Review, p.11 and p.270; Interview with Lord Stephens in BBC Panorama 'Britain's Secret Terror Deals', 26th May 2015.

34 Defence Select Committee, Investigations into Fatalities in Northern Ireland Involving British Military Personnel, HC 1064, Session 2016-17, para. 15

35 Sir Robert (later Lord) Lowry, R v Foxford, [1974] NI 181, at p. 200. 
the army noted in a lecture in 1973, 'the honeymoon period was over. ${ }^{36}$ Between 1969 and 1974, 170 people were killed by the British army. Sixty-three per cent of these were undisputedly unarmed at the time and only $12 \%$ ( 24 people) were confirmed as armed, with a further 14 listed as 'possibly armed'. ${ }^{37}$ There were no criminal prosecutions of state actors during this period. ${ }^{38}$ It is difficult to assert with any credibility that any of these cases were properly investigated, even by the investigative standards of the day, which is why the practice of RMP investigations was ceased. ${ }^{39}$ More generally, as the official Operation Banner review notes, only a dozen or so serious cases involving Army personnel killing or injuring others came to court during the 30 years of the conflict. ${ }^{40}$ In relation to operational shootings the report cites 4 convictions for murder, 1 of which was overturned on retrial. ${ }^{41}$ These figures do not appear to include members of the Ulster Defence Regiment. ${ }^{42}$

With regard to more recent investigations, a highly critical report by Her Majesty's Inspectorate of Constabulary on the work of the Historical Enquiries Team found that 'state involvement cases had been reviewed with less rigour in some areas than non-state cases'. ${ }^{43}$ The former PSNI Chief Constable, Sir Matt Baggott, accepted those criticisms in full and ordered that all 238 military killings should be reviewed afresh. ${ }^{44}$ The reason for the higher number of staterelated cases requiring an effective investigation is the widespread acceptance by criminal justice and legal professionals that they were not properly investigated in the first place.

Similar criticisms concerning the lack of 'balance' have previously been directed against the Public Prosecution Service in Northern Ireland. As noted above, the DPP has initiated legacy

36 The full extract from that lecture - given by an officer identified as Major INQ 3 is reproduced in the Bloody Sunday Inquiry Report Volume IX, p. 234. "Back in 1970 a decision was reached between the GOC and the Chief Constable whereby RMP would tend [sic] to military witnesses and the RUC to civilian witnesses in the investigation of offences and incidents. With both RMP and RUC sympathetic to the soldier, who after all was doing an incredibly difficult job, he was highly unlikely to make a statement incriminating himself, for the RMP investigator was out for information for managerial, not criminal purposes, and, using their powers of discretion, it was equally unlikely that the RUC would prefer charges against soldiers except in the most extreme of circumstances. However, in March 1972, following the imposition of direct rule from Westminster, a Director of Public Prosecutions was appointed for Northern Ireland and he soon made it clear that the existing standards were far from satisfactory. In November 1972 he revoked the RUC's discretionary powers in these matters, ordering all allegations made against the security forces to be passed to him for examination. The honeymoon period was over." Major INQ 3 also gave oral evidence to the Bloody Sunday Inquiry and confirmed that the revoked discretionary powers referred to where those of the RUC deciding whether or not to institute criminal proceedings against an individual solder. No criminal procedures were instigated against any British soldier during this period.

37 Using court records (in particular inquest records), newspapers and other open sources, Professor Fionnuala Ní Aoláin created a database concerning the details of the all of those killed by state actors between 1969-1994. See F. Ní Aoláin (2000) 'The Politics of Force: Conflict Management and State Violence in Northern Ireland - A Brief Historical Overview.' Minnesota Legal Studies Research Paper No. 12-12, p.23.

38 Ibid.

39 In one such case investigated by the Royal Military Police, Mr Justice Kerr held that it was not open to the RUC to delegate the critical responsibilities to investigate a killing to another agency such as the Royal Military Police. He also held that :...the fact that each of the interviews cannot have lasted any more than half an hour; the fact that clear discrepancies appear in the statements made, discrepancies which have not been the subject of further challenge or investigation, are sufficient to demonstrate the inadequacy of the investigation into the death of the deceased.' See In the Matter of an Application by Mary Louise Thompson for Judicial Review [2003] NIQB 80.

40 British Army (2006) An Analysis of Military Operations in Northern Ireland. Available http://www.vilaweb.cat/media/attach/ vwedts/docs/op_banner_analysis_released.pdf p. 46, para 431.

41 Ibid. As above, namely R $\vee$ Thain (1984) R $\vee$ Clegg (1993) (acquitted on retrial in 1999) and R $\vee$ Fisher and Wright (1995). Private Thain was released after serving less than three years of a life sentence and returned to his regiment. Scots Guards Fisher and Wright are discussed below.

42 C. Ryder (1991) The Ulster Defence Regiment: An Instrument of Peace? (Methuen) suggests that 18 UDR soldiers were convicted of murder and 11 of manslaughter during the conflict p.150.

43 HMIC (2013) Inspection of the Police Service of Northern Ireland Historical Enquiries Team. Available at https://www. justiceinspectorates.gov.uk/hmicfrs/publications/hmic-inspection-of-the-historical-enquiries-team/.

44 Belfast Telegraph 3rd July 2013 'Army Killings to be Re-Examined. 
prosecutions in 17 legacy cases; 8 against alleged republican paramilitaries, 4 against alleged loyalists and 5 against British Army personnel ( 6 soldiers in total, one case involves two soldiers). ${ }^{45}$ Again, the notion of an imbalance in prosecutions is simply not supported by the relevant data.

In sum, there is no historical or contemporary evidence to support the claim of a witch-hunt in terms of the proportionate number of legacy investigations or prosecutions against state actors.

\section{'The Early Release Scheme Only Benefitted Paramilitaries'}

A second argument raised in Westminster and elsewhere in favour of a statute of limitations for former soldiers is that such soldiers were not included in the early release scheme established under the Northern Ireland Sentences Act 1998 as a result of the Good Friday Agreement. ${ }^{46}$ The legislation specifies that all prisoners convicted of scheduled offences between 1973 and 1998 who received sentences of over five years imprisonment can apply to the Commission for early release and that all qualifying prisoners had to be released within two years of the signing of the Good Friday Agreement. This has since been interpreted to mean that anyone eligible for the early release for offences committed before 1998 will serve a maximum of two years.

However, it was clear from the outset that soldiers and other state actors were entitled to apply to the same accelerated release scheme as paramilitary prisoners. In 1998, as noted above, the only soldiers imprisoned for conflict-related offences were Guardsmen Fisher and Wright, both of whom had been convicted of murder. Both applied to the Sentence Review Commission and the Commission indicated a willingness to consider them in the same way as paramilitary prisoners. However, as the parliamentary answer from then Security Minister Adam Ingram makes clear, the government took the decision to release them on license under the Prison Act to ensure that they would be released before the early release of paramilitary prisoners commenced later that same week. ${ }^{47}$ This was a political rather than a legal decision. Their eligibility under the Sentence Review scheme was not in question. Former Minister of

45 Letter from Director of Public Prosecutions to Joanne Bunting MLA, 18th October 2019 and letter from Director of Public Prosecutions to Professor Kieran McEvoy, 10th January 2020.

46 See e.g. HC Debates 25th January 2018, Vol, 635. Given Robinson MP, col. 212.

47 Hansard, 28th October 1998, Column 201.

Mr. Dalyell: To ask the Secretary of State for Northern Ireland if she will make a statement on the case of Guardsmen Fisher and Wright. [54784]

Mr. Ingram: Guardsmen Fisher and Wright were released on life licence by the Secretary of State on 2 September 1998. This decision took into account that while the Secretary of State had been carrying out a review of the cases, the Northern Ireland (Sentences) Act 1998 became law. Although she was aware that the Guardsmen had applied to the Sentence Review Commission for early release, the Secretary of State was conscious that the Sentences Act enables the early release of prisoners who were engaged in terrorism. The Guardsmen were in Northern Ireland as a consequence of that terrorism and committed the offence while on duty to counter it. At the time of her decision the Secretary of State was also aware that the first possible releases under the Sentences Act could have taken place from 7 September onwards. Taking all these factors into account and having consulted the Lord Chief Justice as required by statute, the Secretary of State decided that the Guardsmen should be released on life licence under the Prison Act 1953. 
State for the Armed Forces Mark Lancaster confirmed this in the course of a debate on the Defence Select Committee report on Investigations into fatalities in Northern Ireland. ${ }^{48}$

\section{The 'On the Run' Scheme was an 'Amnesty for Paramilitaries'}

A third argument raised in parliament and in the media to support the witch-hunt narrative relates to the 'On the Run' (OTR) Scheme which operated between 2000-2014. ${ }^{49}$ This scheme involved republican suspects receiving 'letters of assurance' as to whether or not they were deemed a person of interest to the police. This scheme came to prominence in February 2014 following the collapse of a murder trial against John Downey, an alleged IRA member accused of involvement in the Hyde Park bombing. The case against Mr Downey collapsed when it became clear that Mr Downey was in fact a person of interest and that he had been given a letter of assurance in error. The trial judge ruled that it would be an abuse of process to try Mr Downey since he had relied upon the erroneous letter to travel to the UK. ${ }^{50}$ That decision was not appealed.

The subsequent review of the scheme was led by Lady Hallett. While she was critical of the scheme operating without a proper structure or policy in place, she was clear that 'the administrative scheme did not amount to an amnesty for terrorists. Suspected terrorists were not handed a 'get of jail free card. ${ }^{51}$ The definition of an amnesty used by Lady Hallett was 'under an amnesty the state agrees never to prosecute for an offence, whatever the strength of the case against an alleged offender. ${ }^{52}$

The fact that the OTR scheme did not constitute an amnesty is further evidenced by the fact that John Downey was subsequently arrested in the Irish Republic under a European Arrest Warrant, extradited to Northern Ireland, and is currently before the courts there charged with the murder of two members of the Ulster Defence Regiment in Northern Ireland in 1972.

48 HC 1064, Session 2016-17, and the Government response, HC 549. See https://www.parliamentlive.tv/Event/Index/ b4c512e0-51c4-4251-adOb-3f6b3f525fbb. In response to a question on whether the Northern Ireland Sentences Act 1998 applied to former soldiers as well as paramilitaries, Mr Lancaster replied (at 15.00:07) 'Yes it does providing the eligibility criteria set out in the Act are met.' Mr Lancaster went on to say that in practice, no members of the security forces had yet been convicted of relevant offences since the passing of the Act so the Act had not yet been used. He also said with regard to the mechanism used to release Guardsmen Fisher and Wright, 'that case does not demonstrate that members of the security forces are debarred from making use of the Northern Ireland Sentences Act.' See also See. e.g. HC Debates 25th January 2018, Vol, 635. col. 223

49 See e.g. HC debate on Private Members Bill Armed Forces (Statute of Limitations) Bill, 1st November 2017, Vol 630, col 824 Richard Menyon MP.

50 R v John Anthony Downey 2014 https://www.judiciary.uk/wp-content/uploads/JCO/Documents/Judgments/r-v-downeyabuse-judgment.pdf

51 Lady Heather Hallett, An Independent Review into the On the Runs Administrative Scheme (2014) p 7. https://assets.publishing.service.gov.uk/government/uploads/system/uploads/attachment_data/file/335206/41003_ Hallett_Web_Accessible.pdf

52 ibid 


\section{Vexatious Litigation and the European Convention on Human Rights}

The most prominent of the more recent themes in the witch-hunt narrative, (repeated in the Queen's Speech in December 2019), is that former members of the security forces are the victims of 'unfair and vexatious claims'.53 Elsewhere in the same Queen's Speech, it states

the Government is strongly opposed to the threat of vexatious litigation in the form of repeated investigations and potential prosecutions arising from historical military operations many years after the events in question. ${ }^{54}$

In effect, the Queen's Speech appears to transpose, erroneously, the idea of 'vexatious' litigation that exists within civil law to the realm of (potentially) criminal investigations into allegations of past crimes and human rights abuses.

Despite its political prominence, there is no precise legal meaning to the term 'vexatious litigation'. A vexatious proceeding has been described in AG v Barker as one that 'has little or no basis in law (or at least no discernible basis)' wherein

its effect is to subject the defendant to inconvenience, harassment and expense out all proportion to any gain likely to accrue to the claimant; and that it involves an abuse of the process of the court...55

In a similar vein, there is no legal definition of a 'vexatious prosecution'. There is an analogous tort of 'malicious prosecution' which has been defined as one (a) wherein the proceedings were found in the defendant's favour, (b) where there was no 'reasonable and probable cause to bring the prosecution' and (c) where the police or prosecutor acted 'maliciously'. ${ }^{56} \mathrm{~A}$ reasonable and probable cause has been defined as

an honest belief in the guilt of the accused based upon a full conviction, founded on reasonable grounds, of the existence of a state of circumstances, which assuming them to be true, would reasonably lead to any ordinarily prudent and cautious man to the conclusion that the person charged was probably guilty of the crime imputed. ${ }^{57}$

Acting maliciously in such a case is an extremely high threshold, requiring that the police or prosecutor's motives were something other than bringing an offender to justice (e.g. revenge) or that the police or prosecutor had fabricated evidence. ${ }^{58}$ Where investigations and prosecutions are conducted for good faith reasons, but are unsuccessful in securing a conviction, this is not evidence that the investigation and trial were vexatious.

Bearing in mind that legacy investigations in Northern Ireland are of the most serious offences (including murder), and that previous investigations have been widely accepted as

53 Queen's Speech Background Briefing Notes 2019, p. 5.

54 Ibid, p. 128

55 [2000] 1 FLR 759

56 D. Young et al (2014) Abuse of Process in Criminal Proceedings (4th edition).

57 Hawkins J in Hicks v Faulkner, 18788 QBD 167, 171 approved and adopted by the House of Lords in Herniman v Smith 1938 AC 305316 per Lord Atkin.

58 D. Young et al op cit. 
substandard in a large number of important cases (see further below), the idea that conflictrelated investigations or prosecutions could be legally described as 'vexatious' or 'malicious' is not intellectually credible.

Moreover, such a view appears to suggest that the Police Service of Northern Ireland (or previously the Historical Enquiries Team) and the Public Prosecution Service have been engaged in unprofessional behaviour, amounting to either vexatious or malicious investigations or prosecutions. With regard to the proposed role of the Historical Investigations Unit, as is detailed in the Draft Stormont House Bill, there are already safeguards built in that require the HIU Director to take into account previous investigations and avoid unnecessary duplication. ${ }^{59}$

Given the gap between the high threshold outlined in law and the reality of how investigations have unfolded, it would appear that the term 'vexatious' is a term of political rather than legal import.

The political origins of the term can be traced in a number of Defence Select Committee reports. ${ }^{60}$ These reports have been highly critical of the legal basis upon which civil actions have been taken by the families of British soldiers killed in Iraq ${ }^{61}$ as well as the ways in which investigations into alleged abuses by British Army personnel have been handled in that theatre. ${ }^{62}$ These civil actions and investigations - and the Defence Select Committee responses to them - are complex and beyond the scope of this paper. However, one central strand which is of direct relevance is the persistent political criticisms of findings by the courts that the European Convention on Human Rights may apply in certain circumstances to the actions of British military abroad. That political frustration in some quarters at the applicability of the ECHR to military conflict overseas, (sometimes confusing the ECHR with the European Union), ${ }^{63}$ has in turn been extended to the application of the ECHR to the Northern Ireland conflict. However, the application of the ECHR within the United Kingdom as compared to overseas is hardly a matter of political controversy.

The ECHR and the Human Rights Act which implemented it into domestic law are now a deeply embedded feature of the legal system across the United Kingdom. For example,

59 Northern Ireland Office (2018) Northern Ireland (Stormont House Agreement) Bill Explanatory Notes para 53.

60 See Defence Committee, UK Armed Forces Personnel and the Legal Framework for Future Operations, Twelfth Report of Session 2013-14, HC 931; Defence Committee, Who Guards the Guardians? MoD Support for Former and Serving Personnel, Sixth Report of Session 2016-17, HC 109; Defence Sub-Committee, 'Drawing a line: Protecting veterans by a Statute of Limitations', 16 July 2019, https://publications.parliament.uk/pa/cm201719/cmselect/cmdfence/1224/1224.pdf, pp. 6-8.

61 In 2013, the Supreme Court held in three cases concerning the deaths and serious injuries of servicemen service in Iraq that the legal obligations owed by the state to British service personnel could fall within the jurisdiction of the ECHR. See Smith and others $v$ the Ministry of Defence, Ellis $v$ the MoD and Allbutt and others $v$ the MoD [2013] UKSC 41

62 C. Ferstman, T. Obel Hansen and N. Arajärvi, The UK Military in Iraq: Efforts and Prospect for Accountability for International Crimes Allegations? Essex and Ulster Universities, 1 October 2018, https:// www.ulster.ac.uk/ data/assets/ pdf_file/0018/317502/THE-UK-MILITARY-IN-IRAQ-1Oct2018.pdf.

63 The European Convention on Human Rights (ECHR) is part of a completely different legal system to the EU. The ECHR and the European Court of Human Rights which enforces it are both part of the Council of Europe which has 47 member states, including the UK. It was established in the wake of the Second World War in response to the Nazi atrocities committed during that conflict, the enactment of what Winston Churchill described in 1948 as 'a Charter of Rights, guarded by freedom and sustained by law.' The UK ratified the ECHR in 1951 and accepted the right to individual petition to the European Court of Human Rights in Strasbourg in 1966. The European Union (EU) consists of 27 Member States, since the UK's departure in 2019. The Court of Justice of the European Union, sometimes referred to as the European Court of Justice, is the body responsible for overseeing compliance with EU law in the EU. Much of EU law historically has focused on making it easier to sell goods, to work and to conduct business within the EU. 


\section{Background}

Article 2 of the European Convention on Human Rights places an obligation on the state to ensure that an independent, effective, prompt and transparent investigation is carried out into any death caused by the state or where it appears that the state has failed to protect someone. The state's obligation to protect the right to life also extends to an obligation to investigate deaths in certain circumstances caused by private non-state actors. ${ }^{64}$ Article 2 has thus been a cornerstone of inquiries such as that into the Hillsborough Disaster and the ongoing Grenfell Tower Inquiry as well as in determining the responsibilities of the police and other state agencies to protect lives in prisons, hospitals and in community settings. In addition, in Northern Ireland the ECHR, is if anything, an even more important feature of the legal and political landscape. The Good Friday Agreement thus committed that the UK government would 'complete incorporation into Northern Ireland law of the European Convention on Human Rights (ECHR), with direct access to the courts, and remedies for breach of the Convention. ${ }^{36}$ 


\section{Conclusion}

In sum, the key arguments which have been deployed to support the 'witch-hunt' narrative against members of the security forces with regard to legacy investigations and prosecutions are neither factually nor legally accurate and lack intellectual credibility.

In the section below, we explore the range of proposals that have been put forward by politicians, law officers, and other key stakeholders as a way of addressing concerns regarding the investigation and prosecution of state actors and others for conflict-related offences. We stress again our position that the implementation of the Stormont House Agreement as agreed in 2014 (Proposal 1 below) offers the best way forward. However, given the prominence of the issue and in order to bring clarity to the debate, we have below analysed the strengths and weaknesses of all of the relevant proposals which have been placed in the public domain regarding conflict-related investigations and prosecutions.

Some of these proposals and suggestions are more developed than others. For ease of reference, we have below summarised each proposal in a table, in which we benchmark the proposal against three key criteria by which we would argue all legacy proposals should be judged:

1 Compatibility with binding international and domestic human rights law, in particular the ECHR (adherence to which is a fundamental part of the Good Friday Agreement).

2 Compatibility with the Good Friday Agreement - the cornerstone of the Northern Ireland peace process.

3 Compatibility with the Stormont House Agreement - which sets out the measures, which have to date, secured the most consensus amongst victims, civil society and politicians concerning dealing with the past. 


\section{Proposal 1:}

\section{Implement the Stormont House Agreement}

\begin{tabular}{|c|c|c|}
\hline $\begin{array}{l}\text { Overview of } \\
\text { Proposal }\end{array}$ & \multicolumn{2}{|l|}{ Implement the Stormont House Agreement } \\
\hline $\begin{array}{l}\text { Source of } \\
\text { proposal }\end{array}$ & \multicolumn{2}{|c|}{$\begin{array}{l}\text { The SHA was agreed in December } 2014 \text { between the five main } \\
\text { NI political parties and the British and Irish governments. }{ }^{66}\end{array}$} \\
\hline $\begin{array}{l}\text { Detail of } \\
\text { proposal }\end{array}$ & \multicolumn{2}{|c|}{$\begin{array}{l}\text { - All police investigations would be undertaken by an independent } \\
\text { Historical Investigations Unit mandated to carry out Article } \\
2 \text { compliant investigations (rather than the PSNI). } \\
\text { - Following investigations by the HIU, any decision to prosecute } \\
\text { would be taken by the Director of Public Prosecutions based on } \\
\text { the prosecutorial test i.e. whether there is a reasonable prospect of } \\
\text { conviction applying both the evidential and public interest test. } \\
\text { - The Draft SHA Bill includes provisions to amend the } \\
\text { Northern Ireland Sentences Act } 1998 \text { to ensure that conflict- } \\
\text { related offences committed before August } 1973 \text { will be } \\
\text { treated the same as those committed after that date. } \\
\text { - Any member of the security forces or paramilitary found } \\
\text { guilty will serve a maximum of two years imprisonment } \\
\text { if they meet the criteria for early release. The decision } \\
\text { on eligibility for release will be taken by the independent } \\
\text { Sentence Review Commission, established under the Good } \\
\text { Friday Agreement via the Northern Ireland Sentences Act. } \\
\text { - The work of the HIU (including the provision of family reports), the } \\
\text { ICIR, OHA, and IRG would be designed to provide a victim-centred } \\
\text { service to victims and survivors which promotes reconciliation. }\end{array}$} \\
\hline $\begin{array}{l}\text { Compatibility } \\
\text { with human } \\
\text { rights } \\
\text { obligations }\end{array}$ & $\begin{array}{l}\text { - The SHA is specifically designed to be compliant } \\
\text { with all human rights obligations, including } \\
\text { Article } 2 \text { of the ECHR which has been interpreted } \\
\text { as creating a right to an independent, prompt, } \\
\text { effective, and transparent investigation, which } \\
\text { is capable of leading to a prosecution. }\end{array}$ & \\
\hline
\end{tabular}

66 Following the Agreement in December 2014, the Ulster Unionist Party ruling executive agreed to 'note' what had been agreed in January 2015. They had expressed concerns about some of the financial aspects of the broader SHA beyond the legacy parts of the Agreement. The then UUP party leader Mike Nesbitt said he had undertaken not to recommend the deal but to give it 'a fair wind'. He said he was not surprised by the outcome of the meeting with members agreeing simply to 'note' what had been agreed. He added 'Remember that they rejected Hillsborough in 2010 and Haass in 2014. They have not rejected this so-called Stormont House Agreement. They are just expressing concerns about how it will be implemented, whether or not there are side deals and whether it really does address the financial difficulties, and these are very severe.' BBC News NI 5th January 2015, Stormont House Agreement: UUP 'right to reserve judgement'. 
- The Good Friday Agreement provides for the incorporation of the ECHR with which this

Compatibility with GFA

Compatibility

with SHA proposal is compatible, provided it is implemented in a human rights compliant manner.

- The mechanism envisaged for the early release of prisoners (the Sentence Review Commission) was established by the Good Friday Agreement.

- The compatibility of the SHA legislation with the original SHA will be dependent on whether the final specific provisions therein represent a 'good faith' implementation of that Agreement. 


\section{Proposal 2:}

\section{A De Facto General Amnesty}

\begin{tabular}{|c|c|c|}
\hline $\begin{array}{l}\text { Overview of } \\
\text { Proposal }\end{array}$ & \multicolumn{2}{|l|}{$\begin{array}{l}\text { General proposal for no further police } \\
\text { investigations, inquests, prosecutions or } \\
\text { inquiries into Troubles-related killings }\end{array}$} \\
\hline $\begin{array}{l}\text { Source of } \\
\text { proposal }\end{array}$ & \multicolumn{2}{|l|}{$\begin{array}{l}\text { This proposal was made by NI Attorney General (AGNI) } \\
\text { John Larkin QC in } 2013 \text { during the Haass talks. }{ }^{67}\end{array}$} \\
\hline $\begin{array}{l}\text { Detail of } \\
\text { proposal }\end{array}$ & \multicolumn{2}{|c|}{$\begin{array}{l}\text { - Ending of all police investigations, prosecutions, inquests, } \\
\text { and inquiries to all conflict-related deaths caused by } \\
\text { paramilitaries, police or the Army up to the } 1998 \text { Agreement. } \\
\text { - Victims to be given 'as much access as possible to official records' } \\
\text { to help them find out what happened to their loved ones. } \\
\text { - While the AGNI argued that his proposals did } \\
\text { not constitute 'a formal amnesty', the ending of } \\
\text { criminal investigations and prosecutions would be } \\
\text { precisely that - a negation of criminal liability. } \\
\text { - The proposal was strongly opposed from across the } \\
\text { political spectrum and was not progressed. }\end{array}$} \\
\hline $\begin{array}{l}\text { Compatibility } \\
\text { with human } \\
\text { rights } \\
\text { obligations }\end{array}$ & $\begin{array}{l}\text { This proposal is incompatible with Article } 2 \text { of the } \\
\text { ECHR, which guarantees the right to an independent, } \\
\text { prompt, effective, and transparent investigation } \\
\text { which is capable of leading to a prosecution. }\end{array}$ & \\
\hline $\begin{array}{l}\text { Compatibility } \\
\text { with GFA }\end{array}$ & $\begin{array}{l}\text { The AGNI argued that his proposals were a logical } \\
\text { outworking of the GFA. However, the GFA provides } \\
\text { for the incorporation of the ECHR, with which the } \\
\text { proposals are incompatible. Furthermore, the GFA } \\
\text { contains no provisions for an amnesty; instead, the GFA } \\
\text { provided for early release of prisoners, who had been } \\
\text { subject to investigation, prosecution, and conviction. }\end{array}$ & \\
\hline $\begin{array}{l}\text { Compatibility } \\
\text { with SHA }\end{array}$ & $\begin{array}{l}\text { The proposal predates the Stormont House } \\
\text { Agreement. However, it would be incompatible with } \\
\text { provisions in the SHA that include investigations } \\
\text { through the HIU, prosecutions by the DPP, and } \\
\text { the continued operation of legacy inquests. }\end{array}$ & \\
\hline
\end{tabular}

67 Kearney, Vincent 'NI attorney general John Larkin calls for end to Troubles prosecutions' BBC News Online 20 November 2013. 


\section{Proposal 3:}

\section{A Statute of Limitations for the Security Forces}

\begin{tabular}{|c|c|}
\hline $\begin{array}{l}\text { Overview of } \\
\text { Proposal }\end{array}$ & $\begin{array}{l}\text { A Qualified Statute of Limitations for Current and } \\
\text { Retired Armed Forces Personnel (with possible } \\
\text { expansion to current and retired police officers) }\end{array}$ \\
\hline $\begin{array}{l}\text { Source of } \\
\text { proposal }\end{array}$ & $\begin{array}{l}\text { - The political origins of this proposal lie in discussions } \\
\text { regarding British army activities in Iraq but this was } \\
\text { subsequently extended to include Northern Ireland. } \\
\text { - In April 2017, the Defence Select Committee published a } \\
\text { report calling for a statute of limitations. }{ }^{68} \text { In November } \\
\text { 2017, a private members' Bill was introduced by a cross-party } \\
\text { group of MPs; draft legislative proposals were then published } \\
\text { in June 2018. These proposed a statute of limitations for } \\
\text { security forces if a killing took place more than ten years } \\
\text { ago. }{ }^{69} \text { The Bill ultimately failed to pass through parliament. } \\
\text { - Amendments were introduced to the Northern Ireland } \\
\text { (Executive Formation) Act } 2019 \text { requiring the NI SoS to } \\
\text { report on progress made towards 'a Qualified Statute of } \\
\text { Limitations or by some other legal mechanism' to 'protect' } \\
\text { armed forces personnel from 'repeated investigations'70 }\end{array}$ \\
\hline
\end{tabular}

68 House of Commons Defence Select Committee (2017) Investigations into Fatalities in Northern Ireland Involving British Military Personnel. An amended proposal, calling for a 'qualified' statute of limitations was called for by the same Committee in 2019. House of Commons Defence Select Committee (2019) Drawing a Line: Protecting Veterans by a Statute of Limitation.

69 Armed Forces (Statute of Limitations) Bill (2018) HC Bill 120.

70 Northern Ireland (Executive Formation etc) Act 2019, 3 (8). This Act also required a report from the SOSNI on a different option regarding prosecutions and the legality or otherwise of the weapon used, discussed further below. 
- Initial variants of this proposal called for a broad statute of limitations for members of the security forces. In its 2017 report, the Defence Select Committee linked this to an unspecified 'truth recovery mechanism' ${ }^{71}$

- In its 2019 report, the Defence Select Committee shifted its position

\section{Detail of} proposal and instead advocated for a 'qualified' statute of limitations that would (a) only apply to cases that had been investigated and in which the accused had been exonerated; and (b) 'provide scope for re-investigation where compelling new evidence emerges'. They continued to advocate for a 'truth recovery mechanism'.

- The Defence Select Committee has also called for amendments to the Human Rights Act to prevent its application to events that took place before October 2000, when the Act entered into effect.

- Any statute of limitations which had the effect of preventing or interfering with effective investigations of conflict-related deaths or torture and inhuman and degrading treatment would violate the ECHR as well as

Compatibility with human rights obligations

- As argued by the former SoSNI in her letter to the Defence Select Committee and by the MOD in their submission to the same committee, the effect of a 'state-actor' only statute of limitations would most likely result in a de facto amnesty for non-state (paramilitary) suspects. ${ }^{73}$

71 Op cit.

72 See e.g. Commission on Human Rights (2005) Updated Set of Principles for the Protection and Promotion of Human Rights Through Action to Combat Impunity. E/CN.4/2005/102/Add.1 Principle 1. 'Impunity arises from a failure by states to meet their obligations to investigate violations; to take appropriate measures in respect of the perpetrators, particularly in the area of justice, by ensuring that those suspected of criminal responsibility are prosecuted, tried and duly punished...' ; See also, Council of Europe (2011) Eradicating Impunity for Serious Human Rights Violations. '...states should take all necessary measures to comply with their obligations under the Convention [ECHR] to adopt criminal law provisions to effectively punish serious human rights violations through adequate penalties. These provisions should be applied by the appropriate executive and judicial authorities in a coherent and non-discriminatory manner.'

73 Letter from Secretary of State for Northern Ireland Karen Bradley to Dr Julian Lewis, Chair Defence Select Committee, 4th July 2018; Written Evidence Submitted by Ministry of Defence to HC Defence Select Committee (2019) Annex The MOD's Response to the Defence Committee's Questions on Statute of Limitations -Veterans' Protection 


\begin{tabular}{|c|c|}
\hline & $\begin{array}{l}\text { - A statute of limitations would be more likely to be } \\
\text { deemed compatible with human rights obligations if it } \\
\text { only applied after an Article } 2 \text { compliant investigation } \\
\text { had been completed, leaving an opportunity for } \\
\text { reinvestigation if new evidence emerged. } \\
\text { - If a statute of limitations were applied to cases } \\
\text { that had not been previously investigated, or } \\
\text { where previous investigations were flawed, it } \\
\text { would not be human rights compliant. } \\
\text { - Compatibility of this proposal with human rights law } \\
\text { rests heavily on how the 'qualified' nature of the statute } \\
\text { of limitation would be implemented in practice. }\end{array}$ \\
\hline $\begin{array}{l}\text { Compatibility } \\
\text { with GFA }\end{array}$ & $\begin{array}{l}\text { The GFA included provisions for sentence reduction } \\
\text { for those convicted of conflict-related offences } \\
\text { but did not envisage a statute of limitations. } \\
\text { - The GFA requires compliance with the ECHR. } \\
\text { Any statute of limitations that prevents effective } \\
\text { investigations as required by the ECHR would } \\
\text { undermine this commitment in the Agreement. }\end{array}$ \\
\hline $\begin{array}{l}\text { Compatibility } \\
\text { with SHA }\end{array}$ & $\begin{array}{l}\text { - None of the participants involved in the SHA } \\
\text { negotiations argued in favour of a statute of } \\
\text { limitations. In addition, the NIO Consultation } \\
\text { on the draft SHA Bill did not include a question } \\
\text { on a statute of limitations, despite pressure } \\
\text { from the Defence Select Committee to do. } \\
\text { - The HIU is intended to investigate, at the least, all } \\
\text { outstanding cases from the HET and OPONI case } \\
\text { lists, together with completed HET investigations } \\
\text { that have been recognised to be flawed. Thus, the } \\
\text { HIU is tasked with investigating cases that have } \\
\text { not previously been effectively investigated. } \\
\text { - A qualified statute of limitations that only } \\
\text { applied to cases once they had been effectively } \\
\text { investigated could potentially be compatible with } \\
\text { HIU investigations, if applied appropriately. } \\
\text { - If a qualified statute of limitations was applied } \\
\text { to prevent investigations into cases that had not } \\
\text { previously been investigated, it would undermine the } \\
\text { work of the HIU and be in clear breach of the SHA. }\end{array}$ \\
\hline
\end{tabular}




\section{Proposal 4:}

\section{Prosecutions of Soldiers Requiring Consent of the Attorney General for England and Wales}

\begin{tabular}{|c|c|}
\hline $\begin{array}{l}\text { Overview of } \\
\text { Proposal }\end{array}$ & $\begin{array}{l}\text { Prosecutions of former service personnel to require } \\
\text { the consent of the Attorney General for England } \\
\text { and Wales (as the Advocate General for NI). }\end{array}$ \\
\hline $\begin{array}{l}\text { Source of } \\
\text { proposal }\end{array}$ & $\begin{array}{l}\text { This proposal came about in the context of a letter from } 150 \text { Tory } \\
\text { MPs and peers to PM Theresa May arguing that the proposed HIU } \\
\text { would be 'completely at odds' with the government's commitment to } \\
\text { the armed forces and would put 'service and security personnel at an } \\
\text { exceptional disadvantage.'74 The full contents of the letter were never } \\
\text { published. In response, the media were briefed that one suggestion } \\
\text { being considered was that the Attorney General for England and } \\
\text { Wales, who also holds the post of Advocate General for Northern } \\
\text { Ireland by virtue of that office (then Geoffrey Cox) would be required } \\
\text { to consent to any potential prosecutions of former service personnel. } \\
\text { The sources for the media briefing in October } 2018 \text { were unnamed } \\
\text { 'Cabinet Sources'. The AG would not confirm whether his } \\
\text { advice had been sought or given on the legality of this proposal } \\
\text { and the Northern Ireland Office refused to comment. }\end{array}$ \\
\hline $\begin{array}{l}\text { Detail of } \\
\text { proposal }\end{array}$ & $\begin{array}{l}\text { No detailed provisions were placed in the public } \\
\text { domain regarding this proposal. It is not clear what, if } \\
\text { anything, has been done to progress the proposal. }\end{array}$ \\
\hline $\begin{array}{l}\text { Compatibility } \\
\text { with human } \\
\text { rights } \\
\text { obligations }\end{array}$ & $\begin{array}{l}\text { Whilst there is limited detail as to its scope, } \\
\text { the intention of the AG consent proposal } \\
\text { would appear to conflict with human rights } \\
\text { obligations relating to combatting impunity. }\end{array}$ \\
\hline
\end{tabular}


- It could also conflict with the procedural obligations of Article 2 ECHR with respect to independence within criminal justice processes. Furthermore, Article 14 ECHR (non-discrimination), read together with Article 2 , could be engaged as a result of the direct differential treatment it would provide former service personnel. It appears the purpose and effect of the proposal is to create a mechanism that can shield members of the armed forces from punishment. That would not constitute an objective and reasonable justification for differential treatment in human rights terms. ${ }^{76}$

- No detail was provided in the media discussion as to whether or not it was envisaged that the AG could interfere with the investigation component of any case against a member of the armed forces. Any such interference would obviously be in contravention of the procedural obligation to carry out an independent investigation under Article 2 of the ECHR.

- A key element of the criminal justice reforms instituted under the Good Friday Agreement was the removal of the AG powers to veto prosecutions. It had previously been used to veto prosecutions of Compatibility security force members and this became a source with GFA of much controversy during the conflict. ${ }^{77}$ For that reason, the GFA-mandated criminal justice review provided that "there should be no power for the Attorney General to direct the prosecutor, whether in individual cases or on policy matters" ${ }^{78}$

76 Article 14 of the ECHR provides that the rights guaranteed by the Convention 'shall be secured without discrimination on any ground such as sex, race, colour, language, religion, political or other opinion, national or social origin, association with a national minority, property, birth or other status'. The ECtHR has determined that sentencing related issues can engage Article 14. See e.g. ECtHR judgment Paraskeva Todorova v. Bulgaria (2010) (no. 37193/07) wherein a member of the Roma minority in Bulgaria successfully challenged a decision by a court there to give her a three year sentence (despite a recommendation for a suspended sentence by the prosecutor) on the grounds that 'an impression of impunity, especially among members of minority groups, who consider that a suspended sentence is not a sentence.'

77 For example, the controversial decision by former Attorney General Sir Patrick Mayhew in 1988 that RUC officers allegedly involved in evidence tampering in the Stalker Sampson 'shoot to kill investigations' should not be prosecuted 'in the public interest and in particular considerations of national security' was widely criticised at the time and caused major tensions in Anglo-Irish relations. The DPPNI had previously concluded that there was evidence of the commission of offences by RUC officers perverting or attempting or conspiring to pervert the course of justice, or of obstructing a constable in the execution of his duty and referred the matter to the AG for consideration of the public interest test. See HC Debate 25 th January 1988 vol 126 cc21-35.

78 A Review of the Criminal Justice System in Northern Ireland (2000), para 4.161. The Justice (Northern Ireland) Act 2002 which enacted the Criminal Justice Review stipulates in section 42 (1) that the Director of Public Prosecutions shall exercise prosecutorial functions independently of any other person, including government and investigators. Under the Act, the DPP does have a consultative relationship with the AGNI and the AG for England and Wales (also known as the Advocate General for Northern Ireland) in relation to reserved matters. This requires the DPP to consult both before issuing or making alterations to the prosecutorial code and before preparing his annual report on how he has exercised his functions during the financial year. Crucially, neither the AGNI nor the AG for GB can interfere with the DPP's decision-making process on prosecutions. 
- Any move to interfere with the independence of the DPP in prosecutorial decision making would represent a fundamental departure from the GFA-inspired reforms.

Compatibility

with SHA

The proposal is incompatible with the Stormont House Agreement, paragraph 35 of which provides that "the decision to prosecute is a matter for the DPP". ${ }^{79}$ 


\section{Proposal 5:}

\section{Prosecution Decisions Based on Whether the Weapon was ‘Lawfully Supplied’}

\begin{tabular}{|c|c|}
\hline $\begin{array}{l}\text { Overview of } \\
\text { Proposal }\end{array}$ & $\begin{array}{l}\text { Prosecution Decisions Based on Whether } \\
\text { the Weapon was 'Lawfully Supplied' }\end{array}$ \\
\hline $\begin{array}{l}\text { Source of } \\
\text { proposal }\end{array}$ & $\begin{array}{l}\text { This proposal was put forward as an amendment by Conservative } \\
\text { MPs during the passage of the NI Executive Formation Bill } 2019 \\
\text { and was adopted with the support of Tory and DUP MPs. }\end{array}$ \\
\hline $\begin{array}{l}\text { Detail of } \\
\text { proposal }\end{array}$ & $\begin{array}{l}\text { - The amendment places a duty on the NI Secretary of } \\
\text { State to 'report on progress' in relation to developing new } \\
\text { prosecution guidance for legacy cases of Troubles-related } \\
\text { incidents by the Attorney General for Northern Ireland. } \\
\text { - It proposed that such guidance should take into account whether } \\
\text { or not the person had been lawfully supplied with a deadly weapon. } \\
\text { - It proposed that there should be a presumption in } \\
\text { favour of prosecuting when the person had not been } \\
\text { lawfully supplied with a deadly weapon. }{ }^{80}\end{array}$ \\
\hline & $\begin{array}{l}\text { - The NIO response to the legality and viability of } \\
\text { this proposal was fairly blunt. It stated: } \\
\text { Under the Justice (Northern Ireland) Act 2002, the AGNI does } \\
\text { not superintend the DPP for Northern Ireland and therefore } \\
\text { is not able to either issue prosecution guidance to the DPP or } \\
\text { direct the DPP to issue such guidance. It is not within the UK } \\
\text { Government's powers to direct the AGNI, recognising that under } \\
\text { the Justice (Northern Ireland) Act 2002, justice is a devolved } \\
\text { matter. The UK Government has no plans to alter the current } \\
\text { division of responsibilities, and independence as between, the } \\
\text { DPP and the AGNI. }{ }^{81} \\
\text { - It is not clear if the term 'lawfully supplied' is intended } \\
\text { to cover service issue weapons only, or whether this } \\
\text { measure could be deployed to impede prosecutions of } \\
\text { loyalist or republican paramilitaries in cases involving } \\
\text { collusion where agents were supplied with weapons } \\
\text { by security force or intelligence agency handlers. }\end{array}$ \\
\hline
\end{tabular}

80 Northern Ireland (Executive Formation etc) Act 2019, 3 (9).

81 Northern Ireland Office (2019) Response Presented to Parliament pursuant to sections 3(1), 3(6), 3(7), 3(8), 3(9) and 3(10) of the Northern Ireland (Executive Formation etc) Act 2019, p. 20. 


\begin{tabular}{|c|c|}
\hline $\begin{array}{l}\text { Compatibility } \\
\text { with human } \\
\text { rights } \\
\text { obligations }\end{array}$ & $\begin{array}{l}\text { Whether limited to officially issued weapons supplied } \\
\text { to members of the security forces, or also extending to } \\
\text { State agents in paramilitary organisations, this measure } \\
\text { is premised on a presumption against prosecution and } \\
\text { hence punishment in such cases regardless of whether } \\
\text { the killing was lawful under the terms of domestic } \\
\text { law, Article } 2 \text { ECHR and broader international law. } \\
\text { As such the mechanism would be open to challenge } \\
\text { under the UK's obligations under international law } \\
\text { to prevent impunity. }{ }^{82} \text { It also engages the procedural } \\
\text { obligations of Article } 2 \text { ECHR, when read with } \\
\text { Article } 14 \text {. A desire to shield members of the security } \\
\text { forces from prosecution for unlawful killings will not } \\
\text { constitute an objective and reasonable justification for } \\
\text { differential treatment in EHCR terms; the deployment } \\
\text { of the mechanism to shield paramilitaries from } \\
\text { prosecution for killings on the basis that the weapon } \\
\text { in question was provided by security force handlers is } \\
\text { also not objectively justifiable in human rights terms. }\end{array}$ \\
\hline $\begin{array}{l}\text { Compatibility } \\
\text { with GFA }\end{array}$ & $\begin{array}{l}\text { - As above, a key element of the criminal justice } \\
\text { reforms instituted under the Good Friday } \\
\text { Agreement was the removal of the AG's powers } \\
\text { to veto prosecutions. Any move to interfere with } \\
\text { the independence of the DPP in prosecutorial } \\
\text { decision-making would represent a fundamental } \\
\text { departure from those GFA inspired reforms. }\end{array}$ \\
\hline $\begin{array}{l}\text { Compatibility } \\
\text { with SHA }\end{array}$ & $\begin{array}{l}\text { - The proposal is incompatible with the Stormont House } \\
\text { Agreement, paragraph } 35 \text { of which provides that } \\
\text { "the decision to prosecute is a matter for the DPP". }\end{array}$ \\
\hline
\end{tabular}




\section{Proposal 6:}

\section{Power to Veto Prosecutions By the AGNI, a 'Commissioner" or a 'Senior Judge"}

\begin{tabular}{|c|c|}
\hline $\begin{array}{l}\text { Overview of } \\
\text { Proposal }\end{array}$ & $\begin{array}{l}\text { Veto by Legacy Commissioner/AGNI or a Specially } \\
\text { Appointed Judge over Investigations, Prosecutions } \\
\text { or Inquests into Security Force Use of Force }\end{array}$ \\
\hline $\begin{array}{l}\text { Source of } \\
\text { proposal }\end{array}$ & $\begin{array}{l}\text { This proposal was suggested by the Attorney General for Northern } \\
\text { Ireland John Larkin QC at his } 2019 \text { Summer School. Noting } \\
\text { that he had discussed the matter with the AGNI, the former } \\
\text { Conservative Party Special Advisor Lord Jonathan Caine referred } \\
\text { to it as 'one possible way forward' in his maiden speech in the } \\
\text { House of Lords. }{ }^{83} \text { A further version of the proposal was set out } \\
\text { in a lecture to a conservative think-tank in March } 2020 .{ }^{84}\end{array}$ \\
\hline $\begin{array}{l}\text { Detail of } \\
\text { proposal }\end{array}$ & $\begin{array}{l}\text { - The original proposal would involve vesting a power in the AGNI or } \\
\text { a Legacy Commissioner to decide whether criminal investigations, } \\
\text { prosecutorial proceedings, or inquests, would be able to proceed in } \\
\text { relation to the use of force by the security forces prior to the GFA. } \\
\text { - This, it was initially proposed, could be progressed by virtue } \\
\text { of an amendment to Section } 3 \text { of the Criminal Law Act } \\
\mathrm{NI} 1967 \text { on reasonable self-defence, with the AGNI or a } \\
\text { Commissioner, wielding a veto over police investigations and } \\
\text { the prosecutorial processes on grounds of lawful use of force. }\end{array}$ \\
\hline & $\begin{array}{l}\text { - The original version of this proposal suggested that this power } \\
\text { should be vested in either a newly created position of a 'legacy } \\
\text { commissioner' or the Attorney General himself. In March } 2020 \\
\text { the AGNI appeared to amend this proposal by suggesting that } \\
\text { the decision on whether or not a soldier should be prosecuted } \\
\text { could be taken by a senior judge involved in a certification } \\
\text { system for state actor prosecutions who would 'take a view } \\
\text { on whether or not it was in the public interest to prosecute.85 }\end{array}$ \\
\hline
\end{tabular}

83 House of Lords Debate, 9th September 2019, Vol 799, Col. 1369.

84 Policy Exchange 'The ECHR and the future of Northern Ireland's past' Keynote Speech By John Larkin QC, published 20 March 2020.

85 The Times, March 13th, 2020 'Attorney-General Calls for law Change to Shield Army Veterans.' 


\begin{tabular}{|c|c|}
\hline $\begin{array}{l}\text { Compatibility } \\
\text { with human } \\
\text { rights } \\
\text { obligations }\end{array}$ & $\begin{array}{l}\text { - Given that investigating police officers, prosecutors } \\
\text { and judges would already consider reasonable self- } \\
\text { defence for any security force member involved in a } \\
\text { conflict-related killing, changing the law to expand } \\
\text { the meaning of this term in order to facilitate a de } \\
\text { facto veto over such cases proceeding conflicts with } \\
\text { the UK's international legal obligations to prevent } \\
\text { impunity. As such it would also engage compliance } \\
\text { with ECHR Article } 2 \text { when read with Article } 14 \text {. } \\
\text { As with previous proposals, a mechanism that is } \\
\text { explicitly designed to simply shield members of the } \\
\text { security forces from punishment will not constitute an } \\
\text { objective and reasonable justification for differential } \\
\text { treatment when read, in particular, with the duty } \\
\text { to conduct Article } 2 \text { compliant investigations. } \\
\text { - Any interference in the investigative process } \\
\text { would be in contravention of the procedural } \\
\text { obligations to carry out an independent } \\
\text { investigation under Article } 2 \text { of the ECHR. }\end{array}$ \\
\hline $\begin{array}{l}\text { Compatibility } \\
\text { with GFA }\end{array}$ & $\begin{array}{l}\text { - As above, a key element of the criminal justice } \\
\text { reforms instituted under the Good Friday Agreement } \\
\text { was the removal of the power of the AG to veto } \\
\text { prosecutions. Any move to interfere with the } \\
\text { independence of the DPP in prosecutorial decision- } \\
\text { making by the AG, a legacy commissioner or indeed } \\
\text { a senior judge would represent a fundamental } \\
\text { departure from those GFA inspired reforms. }\end{array}$ \\
\hline $\begin{array}{l}\text { Compatibility } \\
\text { with SHA }\end{array}$ & $\begin{array}{l}\text { - The proposal is incompatible with the Stormont House } \\
\text { Agreement, paragraph } 35 \text { of which provides that } \\
\text { "the decision to prosecute is a matter for the DPP." }\end{array}$ \\
\hline
\end{tabular}




\section{Proposal 7:}

\section{A Legacy Commission as an Alternative to Prosecution}

\begin{tabular}{|c|c|}
\hline $\begin{array}{l}\text { Overview of } \\
\text { Proposal }\end{array}$ & A Legacy Commission as an Alternative to Prosecution \\
\hline $\begin{array}{l}\text { Source of } \\
\text { proposal }\end{array}$ & $\begin{array}{l}\text { This proposal was put forward in a submission to the Northern } \\
\text { Ireland Office consultation on the SHA legislation by Barra } \\
\text { McGrory QC, the former DPP for Northern Ireland. }{ }^{.6}\end{array}$ \\
\hline $\begin{array}{l}\text { Detail of } \\
\text { proposal }\end{array}$ & $\begin{array}{l}\text { - This proposal suggests that it is time for our political and civic } \\
\text { leaders to urgently redefine what is understood by 'justice' in } \\
\text { our legal and historical context and to find a solution that is } \\
\text { both innovative and bold. While Mr McGrory makes no claim to } \\
\text { have definitive answers, he expresses deep concerns about the } \\
\text { viability of running a criminal justice-based process in parallel } \\
\text { with an alternative 'truth and information' process (the ICIR). } \\
\text { - He questions the viability of achieving many prosecutorial } \\
\text { outcomes given the passage of time and suggests that the } \\
\text { fact that those who are eventually convicted after years of } \\
\text { fraught investigations will then be released after a short period } \\
\text { of time under the terms of the Good Friday Agreement may } \\
\text { undermine confidence in the criminal justice system. } \\
\text { - He raises concerns about the prospect of families who } \\
\text { are dissatisfied with the failure of the HIU to bring a } \\
\text { criminal prosecution taking civil actions which would in } \\
\text { turn add to the burden of the civil justice system which is } \\
\text { already 'creaking' under the weight of the existing 'legacy' } \\
\text { caseload between civil actions and judicial reviews. } \\
\text { - Mr McGrory proposed an alternative system in which a Legacy } \\
\text { Commission would be established made up of appointed } \\
\text { judges to address all outstanding legacy deaths. He argues } \\
\text { that the HIU should be established but that it should channel } \\
\text { its findings into a tailor-made judicial process which replaces } \\
\text { criminal prosecutions, inquests, and civil proceedings. }\end{array}$ \\
\hline
\end{tabular}

86 Mr McGrory submitted this proposal in his personal capacity after he left the office of the DPP. We are grateful to Mr McGrory for providing us with a copy of his proposal. 
- He further stated:

'The HIU would investigate and gather the information to be forwarded to the Commission with draft findings or recommendations in respect of responsibility for events. It may be clear in many cases that there is simply insufficient evidence to come to any conclusions as to liability on the civil standard and in such circumstances the HIU could issue a family report, similar to those issued by the HET. In cases where a certain evidential threshold is considered to have been met, a lower judicial tier within the Commission could determine which cases should go to full hearings before the upper judicial tier. Full hearings would be like inquests and the presiding Commissioner would have powers to make findings concerning individual and collective culpability.'

The paper itself states that the proposals would require 'participants to forgo existing fundamental

Compatibility with human rights obligations

\section{Compatibility} with GFA

Compatibility with SHA legal rights' and raises the question of compatibility with ECHR Article 2, stating that the submission cannot resolve this but suggests that

the ECtHR would look sympathetically on any comprehensive attempt to address the issue of legacy deaths that meets with broad political agreement.

The post-GFA justice reforms led to the strengthening of the independence of the DPP. Unlike other proposals that would reverse some of the reforms and reinstate a prosecutorial role in the AG, this is not proposed but rather an alternative post-HIU Legacy Commission is to be established applying to all cases, which does not present the same conflict with the GFA.

The proposal is explicitly presented as an alternative to the SHA. It would maintain the HIU as part of the proposal but would not refer cases on to the PPS and would curtail legacy inquests that are set to continue as a separate process under the SHA, albeit to introduce a similar process. It is not clear where the proposal stands on the establishment of the ICIR. 


\section{Proposal 8:}

\section{The March 2020 Northern Ireland Office Proposal}

\begin{tabular}{|c|c|}
\hline $\begin{array}{l}\text { Overview of } \\
\text { Proposal }\end{array}$ & The March 2020 Northern Ireland Office Proposal \\
\hline $\begin{array}{l}\text { Source of } \\
\text { proposal }\end{array}$ & $\begin{array}{l}\text { This proposal was set out as government policy in the Written } \\
\text { Ministerial Statement by the NIO of } 18 \text { March } 2020 .{ }^{87} \text { It coincided } \\
\text { with the introduction into Westminster of the Overseas Operations } \\
\text { (Service Personnel and Veterans) Bill, which will limit the ability to } \\
\text { prosecute British soldiers for war crimes abroad (including torture } \\
\text { and extrajudicial killings). Noting the introduction of that Bill, the } \\
\text { statement made clear its intent was 'to ensure equal treatment } \\
\text { of Northern Ireland veterans and those who served overseas'. }{ }^{88}\end{array}$ \\
\hline $\begin{array}{l}\text { Detail of } \\
\text { proposal }\end{array}$ & $\begin{array}{l}\text { - While the proposal is lacking in detail, it commits the UK } \\
\text { Government to shifting 'the focus of our approach to the } \\
\text { past' to information recovery, whilst stating there will be a } \\
\text { route to justice in a small number of cases, with a suggestion } \\
\text { this will assist reconciliation and 'deliver for victims'. } \\
\text { - It is proposed 'one independent body' will 'oversee and manage' } \\
\text { the information recovery and investigative aspects of the legacy } \\
\text { system, providing 'every family' with a Family Report for each } \\
\text { death. It unclear whether this would mean merging the functions } \\
\text { of the Historical Investigations Unit and the Independent } \\
\text { Commission on Information Retrieval proposed under the Stormont } \\
\text { House Agreement into one mechanism or having an overarching } \\
\text { body overseeing the work of these and the other SHA mechanisms. } \\
\text { - The statement includes the line 'The Government is committed } \\
\text { to the rule of law but.... The desire to 'swiftly implement' an } \\
\text { information recovery mechanism appears to justify interference } \\
\text { with the rule of law. At the same time, it commits the state } \\
\text { to the conduct of 'quick' police investigations in select cases } \\
\text { where there is 'new compelling' evidence and a 'realistic } \\
\text { prospect of a prosecution'. There is no mention of grave or } \\
\text { serious security force misconduct being investigated. Once } \\
\text { such 'quick' investigations are completed, there would be a } \\
\text { statutory bar on the same case ever being investigated again. }\end{array}$ \\
\hline
\end{tabular}

Secretary of State for Northern Ireland, Addressing Northern Ireland Legacy Issues: Written statement - HLWS163 (18 March 2020) https://www.parliament.uk/business/publications/written-questions-answers-statements/written-statement/ Lords/2020-03-18/HLWS163/ 


\begin{tabular}{|c|c|c|}
\hline & \multicolumn{2}{|c|}{$\begin{array}{l}\text { - Cases which are reviewed and where sufficient 'compelling } \\
\text { new evidence' to require investigation and potentially } \\
\text { referral to the DPP is not identified will be 'closed and no } \\
\text { further investigations and prosecutions would be possible'. } \\
\text { This is intended to give all participants 'the confidence } \\
\text { and certainty' to enable persons with information about } \\
\text { deaths to engage with the information recovery process. }\end{array}$} \\
\hline $\begin{array}{l}\text { Compatibility } \\
\text { with human } \\
\text { rights } \\
\text { obligations }\end{array}$ & $\begin{array}{l}\text { Whilst vague and contradictory, the proposals } \\
\text { appear to run contrary to the investigative } \\
\text { duty (under the EHCR and other international } \\
\text { obligations) in the vast majority of cases. } \\
\text { The statement makes a distinction between } \\
\text { 'investigations which are necessary' - which are defined } \\
\text { as cases in which there is 'a realistic prospect of a } \\
\text { prosecution as a result of new compelling evidence } \\
\text { would proceed to a full police investigation and if } \\
\text { necessary, prosecution' - and the rest in which family } \\
\text { reports would be provided. It is difficult to see how the } \\
\text { latter cases (which would inevitably represent the vast } \\
\text { bulk of the caseload, given the challenges in meeting } \\
\text { the 'realistic prospect' threshold) could meet the } \\
\text { Article } 2 \text { requirements for an effective investigation. } \\
\text { Key benchmarks in assessing whether such a } \\
\text { process could be Article } 2 \text { compliant would be } \\
\text { (a) the independence of those involved in the } \\
\text { review/investigation; (b) its effectiveness: whether } \\
\text { those involved had access to all of the relevant } \\
\text { information in order to make an informed decision } \\
\text { regarding which route to take; (c) how access to } \\
\text { all information could be achieved without full } \\
\text { police powers being exercised in the information } \\
\text { gathering phase; and (d) a sufficient element of } \\
\text { public scrutiny of the investigation or its results. } \\
\text { In sum, it is far from clear that this would be an } \\
\text { Article } 2 \text { compliant process. With too high a threshold } \\
\text { for the use of police powers to investigate, and an } \\
\text { obligation to close cases forever once the process is } \\
\text { completed, the process would not adequately expose } \\
\text { human rights violations, and thus would not facilitate } \\
\text { guarantees of non-recurrence, justice or truth recovery. }\end{array}$ & \\
\hline
\end{tabular}




\begin{tabular}{|c|c|}
\hline & $\begin{array}{l}\text { The prospect of no investigations into grave and } \\
\text { serious security force misconduct, in a context } \\
\text { whereby evidence of official criminal wrongdoing } \\
\text { will likely have been destroyed therefore precluding } \\
\text { investigation, also falls short of EHCR duties. } \\
\text { The language suggests the 'new evidence' trigger } \\
\text { will be set higher than the threshold required } \\
\text { by the EHCR. In addition, the subsequent } \\
\text { blanket 'closed cases' procedure prevents } \\
\text { investigation when there is subsequently new } \\
\text { evidence, however 'compelling' it may be. } \\
\text { As regards duties for a 'prompt' investigation, the } \\
\text { NIO written statement bemoans the fact that } \\
\text { 'many families have waited too long to find out } \\
\text { what happened to their loved ones' and suggests } \\
\text { the 'cycle of investigations' has undermined } \\
\text { attempts to come to terms with the past. It fails, } \\
\text { however, to acknowledge the UK government's } \\
\text { responsibility for these delays, as a result of } \\
\text { failure to implement the SHA agreed in } 2014 \text {. }\end{array}$ \\
\hline $\begin{array}{l}\text { Compatibility } \\
\text { with GFA }\end{array}$ & $\begin{array}{l}\text { Whilst vague and unclear, the proposals appear } \\
\text { to dispense with the post-GFA justice reforms } \\
\text { in relation to the test for prosecution and the } \\
\text { independence of the Public Prosecution Service. } \\
\text { It is also possible, given the ECHR-incompatibility } \\
\text { of aspects of the proposals, that enabling legislation } \\
\text { would seek to amend the Human Rights Act to } \\
\text { dispense with procedural obligations tied to the } \\
\text { right to life. This would breach the GFA obligation } \\
\text { to fully incorporate the EHCR into NI law. }\end{array}$ \\
\hline $\begin{array}{l}\text { Compatibility } \\
\text { with SHA }\end{array}$ & $\begin{array}{l}\text { - The proposals explicitly depart from the SHA with } \\
\text { the suggestion that the } 2014 \text { SHA was an important } \\
\text { 'milestone' that 'did not stop the debate continuing'. } \\
\text { It suggests that the proposals have evolved in } \\
\text { alignment with the 'principles of the Stormont } \\
\text { House Agreement', rather than the Agreement itself. }\end{array}$ \\
\hline
\end{tabular}


- The NIO written statement is silent on the fate of the HIU, the Oral History Archive, and the ICIR (including the international treaty which underpins the latter). ${ }^{89} \mathrm{It}$ is ambiguous and unclear as to whether these institutions are to be subsumed into the new unnamed 'one independent body' or if this body is to 'oversee and manage' the existing SHA mechanisms.

- The relationship between 'investigation' and 'information recovery' is already addressed in the proposed structure of the HIU. The HIU provides for a two-stage 'review' and full 'investigation' where there are evidential leads, but with thresholds tied to the ECHR. However, it was always envisaged that the bulk of the work carried out by the HIU would be focused on information recovery. Given the small number of successful prosecutions anticipated, it is acknowledged that the key outcome for the vast majority of victims and survivors would be the family reports. However, the key added value of the HIU was 'information recovery with teeth' - an independent investigative mechanism with full police powers and with access to all relevant open and closed source material.

- The ICIR was to provide a 'firewalled' separate route to information recovery through protected statements. It is not clear how institutional independence could be managed in one body. Indeed, given that a small number of prosecutions would be still possible, it is not clear how the information recovery function of the ICIR would be workable if it were merged with the HIU. 


\section{Proposal 9:}

\section{The Innocent Victims United 'LIB to Replace HIU Proposal'}

\begin{tabular}{|c|c|}
\hline $\begin{array}{l}\text { Overview of } \\
\text { Proposal }\end{array}$ & $\begin{array}{l}\text { The Innocent Victims United (IVU) March } 2020 \\
\text { proposed LIB as an alternative to the HIU }\end{array}$ \\
\hline $\begin{array}{l}\text { Source of } \\
\text { proposal }\end{array}$ & $\begin{array}{l}\text { This proposal was published on the } 21 \text { March } 2020 \text { by IVU / } \\
\text { South East Fermanagh Foundation (SEFF). }{ }^{90} \text { The proposal is } \\
\text { set out over three pages with a summary cover page and an } \\
\text { appendix containing seven Principles of Elementary Justice. }\end{array}$ \\
\hline $\begin{array}{l}\text { Detail of } \\
\text { proposal }\end{array}$ & $\begin{array}{l}\text { - The IVU proposal suggests that the existing Legacy Investigations } \\
\text { Branch in the PSNI could be enhanced to undertake police- } \\
\text { type legacy investigations into some Troubles-deaths instead } \\
\text { of the HIU. The enhanced LIB would be led by an additional } \\
\text { PSNI Deputy Chief Constable (DCC) from outside NI, leading } \\
\text { a team of police detectives (that could be from NI). } \\
\text { - The potential for a Judge-led Oversight Panel (OSP) is also } \\
\text { alluded to as an additional layer of transparency. The OSP, } \\
\text { should it also be established, would reconsider/approve } \\
\text { any DCC decision to re-investigate a particular case. } \\
\text { - LIB case remit: Reference is made to 1,130 potential cases } \\
\text { already on the LIB books. The proposal implies that legacy } \\
\text { cases currently dealt with by the Office of the Police } \\
\text { Ombudsman would instead be included in the LIB remit. The } \\
\text { proposal states in several places however that the remit will } \\
\text { not extend to RUC misconduct in relation to a death (as is } \\
\text { currently the case in 'grave and exceptional' matters for the } \\
\text { Police Ombudsman which would be replicated in the HIU). }\end{array}$ \\
\hline
\end{tabular}

90 https://seff.org.uk/category/innocent-victims-united/ https://www.facebook.com/SEFF.Victims/photos/ pcb.1593902864066707/1593895554067438/?type=3\&theater 
- LIB investigation criteria: The proposal suggests that the LIB would review cases and refer them for full investigation only if stringent criteria are met. The first criterion is that there is 'new evidence' capable of leading to 'the identification of a person criminally involved in a death' AND 'the prosecution of a person for a criminal offence relating to the death' (original emphasis). The second criterion defines 'new evidence' as evidence not previously known to investigators or evidence where the relationship to the death was not previously known. The third criterion prohibits the opening of an investigation on the basis of an allegation of the 'much maligned' term of 'collusion' or the 'protection of an informant' unless there is evidence of 'a substantive criminal offence by an identifiable perpetrator' (original emphasis). The fourth criterion incorporates a further public interest test to be met to open cases, this would debar investigations if the suspect is deceased or 'of a physical or mental state that he/ she could not be safely cautioned, interviewed or face a trial.'

- LIB Family Reports: The IVU proposal is heavily critical of the prospect of the HIU providing all victims' families with 'Comprehensive Family Reports' in cases that it had reviewed or investigated. The IVU proposal would only issue Family Reports (which are to be issued by the OSP and not the LIB) in the limited number of cases where there is a full LIB investigation (and there is no conviction). Furthermore, the OSP Family Report content would be stripped back as they would be debarred from containing any findings. Rather they must contain only 'factual evidential material'. In particular, it is singled out that the LIB should not have the power to criticise RUC misconduct and Family Reports could not identify, 'or allow any means of identifying' any individuals who have been subject to investigation but not prosecuted. 
- The central logic of the IVU proposal (and hence rationale for the enhanced LIB proposal) derives from the contention that the HIU would combine the roles of investigation and adjudication and would therefore be 'contrary to constitutional principle in the United Kingdom'. The authority for this contention is unclear. No specific constitutional principle is pointed to (beyond the UK being a democratic society under the rule of law). Such criticisms have previously been raised by the Northern Ireland Retired Police Officers' Association (NIRPOA) with regard to the ability of the Police Ombudsman to make findings in its legacy reports that criticise the RUC. The reality is that numerous institutions within the UK have both an investigative and adjudicatory function, including the Parliamentary and Health Service Ombudsman, the Prisoner Ombudsman and of course the Police Ombudsman for Northern Ireland.

- The Innocent Victims United proposal also advocates that the LIB, whilst it is investigating criminality, provides 'support and assistance' to the persons it is investigating (whether 'retired officers, veterans' or others). This support and assistance are to be equivalent to that provided to victims and their families.

- The IVU proposal also envisages similar units to the LIB being established in both Great Britain and the Republic of Ireland to undertake parallel work in their respective jurisdictions.

The proposal is incompatible with the EHCR and related human rights standards in a number of respects.

- First, as the LIB is located within the PSNI, the independence requirements of the ECHR are not met. The proposal envisages the LIB subsuming the legacy role of the Police Ombudsman and the

\section{Compatibility} with human rights obligations PSNI investigating the RUC, yet the PSNI directly remains legally liable for the actions of the RUC. An externally recruited individual to the rank of Deputy Chief Constable within the PSNI would not satisfy this independence requirement. While the document

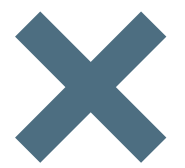
does suggest that the Oversight Panel (OSP) could serve as an appeal mechanism for families/ interested parties aggrieved by an LIB decision, the detail on the OSP focuses on operationally limiting the circumstances in which a case could be reinvestigated. The hierarchical command structure of the LIB within the PSNI would remain. 
- Second, the criteria for LIB reinvestigation falls short of what is required by Article $2 \mathrm{ECHR}$ when there is new evidence as set out in Brecknell $v U K^{91}$ in relation to evidence as to a possible perpetrator of an unlawful killing. This includes sensitivity to material that may undermine the conclusions of an earlier investigation, and the potential for nonprosecutorial sanctions. The additional 'public interest' test and qualified bar on investigating cases contained in the proposal on the basis of collusion or informant protection allegations, also conflict with ECHR and broader human rights compliance, including standards related to impunity. The criteria outlined in the proposal appear to be designed to limit the circumstances in which the LIB can investigate. In particular, if the understanding is that covert practices of facilitating informant involvement in serious crime were 'lawful', the LIB would be largely debarred from investigating cases involving collusion.

- The third area relates to the restrictions on the LIB process in making findings. Article 2 requires that where the State has used lethal force there must be 'independent and public scrutiny capable of leading to a determination of whether the force used was or was not justified in a particular set of circumstances'. ${ }^{2}$ The investigation must also identify state officials or authorities involved in whatever capacity in the chain of events, the planning and control of an operation, and the establishment of the facts as well as, where appropriate, identification and punishment of responsible persons. ${ }^{93}$

- Finally, the proposal from Innocent Victims United does not focus on victims per se but on the rights of the accused person to due process; in particular former RUC officers. Whilst this is an important consideration, the proposals extend protections in a manner which conflicts with ECHR duties, including the prohibition on making determinations beyond criminal liability in relation to RUC conduct, and the express limitations on investigating collusion.

91 Brecknell v United Kingdom (2008) 46 EHRR 957, para 71. 'The Court (ECtHR) takes the view that where there is a plausible, or credible, allegation, piece of evidence or item of information relevant to the identification, and eventual prosecution or punishment of the perpetrator of an unlawful killing, the authorities are under an obligation to take further investigative measures.'

92 Kaya v Turkey (1999) 28 EHRR $122729 / 93$

93 Öneryıldız v. Turkey [GC] - 48939/99 Judgment 30.11.2004 [GC], Al-Skeini v UK [GC] 55721/07, Judgment 07.07.2011, Mustafa Tunç and Fecire Tunç V. Turkey 24014/05 14.05.15 


\begin{tabular}{|l|l|}
\hline & $\begin{array}{l}\text { The proposals are in general incompatible with } \\
\text { the GFA due to incompatibility with the ECHR. In } \\
\text { relation to compatibility with the post-GFA policing } \\
\text { accountability framework: the IVU proposal explicitly } \\
\text { provides that the enhanced LIB will be accountable to } \\
\text { both the Policing Board and PSNI Code of Ethics, and } \\
\text { hence is consistent in this area. However, there is no } \\
\text { with GFA }\end{array}$ \\
$\begin{array}{l}\text { reference as to whether the LIB will be accountable to } \\
\text { the Police Ombudsman. The proposal rolls back the } \\
\text { GFA policing reforms by re-instating the position that } \\
\text { the police can investigate themselves. Such matters } \\
\text { are presently deferred by statute to the Ombudsman. }\end{array}$ \\
\hline $\begin{array}{l}\text { Compatibility } \\
\text { with SHA }\end{array}$ & $\begin{array}{l}\text { The proposal is critical of the SHA and is explicitly } \\
\text { set out as an alternative to the HIU. It is however } \\
\text { silent on the fate of the other SHA envisaged } \\
\text { institutions (ICIR, Oral History Archive, IRG) } \\
\text { and the continued operation of inquests. }\end{array}$ \\
\hline
\end{tabular}




\section{Proposal 10:}

\section{Implement the SHA, Reduce Conflict-Related Imprisonment from Two years to Zero, Based on Cooperation with the ICIR}

\begin{tabular}{|c|c|}
\hline $\begin{array}{l}\text { Overview of } \\
\text { Proposal }\end{array}$ & $\begin{array}{l}\text { Implement the SHA, Reduction of Conflict- } \\
\text { Related Imprisonment to Zero Based } \\
\text { on Cooperation with the ICIR }\end{array}$ \\
\hline $\begin{array}{l}\text { Source of } \\
\text { proposal }\end{array}$ & $\begin{array}{l}\text { This proposal was discussed by Professor Kieran McEvoy on } \\
\text { behalf of the Model Bill Team in Written and Oral Evidence to } \\
\text { the Defence Select Committee in March } 2017 .{ }^{44} \text { The commentary } \\
\text { below offers a more detailed elaboration of that proposal. }\end{array}$ \\
\hline $\begin{array}{l}\text { Detail of } \\
\text { proposal }\end{array}$ & $\begin{array}{l}\text { - Passage of Stormont House Agreement Bill would } \\
\text { include amendments to the operation of the Independent } \\
\text { Commission on Information Retrieval and the Northern } \\
\text { Ireland Sentences Act (1998) concerning the operation } \\
\text { of the Sentence Review Commission (SRC). } \\
\text { - The revised SHA Act would include provision for the ICIR } \\
\text { to issue a 'statement of full cooperation' with regard to any } \\
\text { individual tried and sentenced for NI conflict-related offences. } \\
\text { - The revised NI Sentences Act would include an amended } \\
\text { criterion for the Sentence Review Commission in determining } \\
\text { eligibility for early release for such offences. In addition to } \\
\text { the standard criteria which allow release after two years } \\
\text { imprisonment, the amendment would add an additional } \\
\text { criterion that would allow even earlier release based on } \\
\text { consideration of 'a statement of full cooperation' from the ICIR. } \\
\text { - Immediately following a trial, any individual pleading guilty or } \\
\text { found guilty regarding such offences, who had engaged with or } \\
\text { who indicated a willingness to engage with ICIR, would be granted } \\
\text { immediate temporary release in order to facilitate that engagement. }\end{array}$ \\
\hline
\end{tabular}

94 K. McEvoy (2017) Amnesties, Prosecution, and the Rule of Law in Northern Ireland. Submission to the Defence Select Committee. 
- Upon completion of that process of engagement (either directly or through an interlocutor), the ICIR would determine whether or not to issue the 'statement of full cooperation' in confidence to the SRC.

- If a statement of full cooperation were granted by the ICIR, this would result in an automatic reduction of time served to zero by the SRC.

- Any individual who was not granted such a 'statement of full cooperation', or who refused to engage with the ICIR, would be assessed for eligibility for early release by the SRC in the normal fashion. Such an individual would be liable to serve a maximum of two years imprisonment if deemed eligible for early release as per the terms of the Good Friday Agreement 1998.

\section{REVISED LEGACY SENTENCE REVIEW PROCESS}

\section{Stage One: Investigation}

- Where relevant, the HIU would carry out Article 2 compliant investigations into conflict-related deaths. On completion of those investigations, it would complete a criminal investigation report that would be passed to the DPP.

\section{Stage Two: Decision to Prosecute}

- Applying the evidential and public interest tests, the DPP would make a determination as to whether a conflict-related prosecution should be instituted in the normal fashion.

\section{Stage Three: Trial}

- In cases where a prosecution was instigated, a trial would take place. If the incident in question took place in $\mathrm{NI}$, this will normally be in a juryless trial (formerly known as a 'Diplock' court)..$^{95}$ As happens currently, if the individual pleads guilty or is found guilty, the judge would issue a sentence (e.g. a mandatory life sentence in the case of murder) in the full knowledge that the actual release date will be determined by the SRC.

\section{Stage Four: Temporary Release to Facilitate Engaging with the ICIR}

- Immediately after a person is sentenced, if they had either previously engaged with or indicated a willingness to engage with the ICIR, that individual would be released temporarily pending the completion of the ICIR engagement and verification process and a final determination by the SRC on eligibility. 


\section{Stage Five: Engagement with the ICIR}

- Engagement with the ICIR can be done before, during or after a trial. It can also be done directly or through an interlocutor. The engagement with the ICIR would relate specifically to the offence for which the individual has been convicted and for their own involvement in that offence. It would not require the convicted individual to implicate other named individuals in criminal behaviour. Of course, an individual may wish to engage with the ICIR about incidents beyond that for which he/she has been convicted, but a failure to do so would not constitute grounds for denying a statement of full cooperation.

- Similarly, the involvement of an interlocutor in the process of engagement with the ICIR would have no bearing on whether or not a statement of cooperation would be issued. Once the ICIR were satisfied as to the credibility of the information provided by an individual, it would make a determination as to whether or not a statement of full cooperation was warranted and provide this to the SRC.

- Subject to the statutory restrictions already contained in the ICIR, ${ }^{96}$ the information provided to the ICIR would be included in any family report, triggered by an eligible family member affected by the incident in question, following the ICIR's determination as to its credibility.

\section{Stage Six: Sentence Review Commission Determination on Release}

- If the convicted individual had previously cooperated with or now wished to cooperate with the ICIR, the SRC determination would be delayed pending completion of the ICIR engagement process and ICIR decision on whether a statement of cooperation should be issued. Following completion of the information recovery process, the SRC would determine whether or not the individual satisfies the criteria for additional early release and would make its determination.

- If a statement of cooperation were granted by the ICIR, and the individual satisfied the criteria from eligibility for early release, this would result in an automatic reduction of time served to zero by the SRC. 


\section{Design Challenges}

- Timing: The legislation would need to be passed before cases currently before the courts have concluded to enable those individuals to benefit from the potential sentence reduction for cooperation with the ICIR.

- The statement of full cooperation: What are the criteria for its issuance? What does the statement say? E.g. ICIR confirms to the SRC 'We are satisfied that $x$ person and/or his/her interlocutor have given all relevant and credible information in their possession about their role in this case.' How would such information be verified? How would the confidentiality of ICIR contributors be protected given the public nature of the associated trial? Is there a danger that the focus on securing a statement of cooperation with respect to a specific prosecution would inhibit rather than encourage the sharing of information about other crimes?

- What is the mechanism to facilitate sentence reductions for people convicted of offences other than murder (e.g. attempted murder, membership, etc.)? It would seem anomalous if only people convicted of murder or manslaughter could benefit from a sentence reduction potentially to zero for cooperation with the ICIR whereas those convicted of lesser offences could not. Can the ICIR terms of reference be changed to include a specific role for the consideration of certifying full cooperation regarding such lesser charges?

- What is the mechanism to facilitate temporary release immediately after sentencing to facilitate engagement with the ICIR prior to a final determination as to whether an individual qualifies for early release? The most obvious mechanism is Rule 27 of the Prison and Young Offenders Rules Northern Ireland (1995). Rule 27(1) which states 'A prisoner to whom this rule applies may be temporarily released for any period or periods and subject to any conditions.'

- The ICIR is also envisaged as a cross-border body underpinned by an international treaty between the UK and Irish governments and requiring separate legislation in being passed in Dáil Éireann. Logically, if a decision was made to permit a reduction in sentences for pre-1998 conflict in the United Kingdom in return for full cooperation with the ICIR, a similar arrangement would be required in the Republic of Ireland. ${ }^{97}$

97 The analogous legislation which enacted the early release of qualifying prisoners in the Republic of Ireland is the Criminal Justice Release of Prisoners Act (1998). That legislation created an advisory Release of Prisoners Commission, but unlike in Northern Ireland, the decision-making responsibility on who is eligible for early release, whether and when they will be released remains entirely with the Minister for Justice. The unfettered nature of this discretion has been confirmed by the Irish Supreme Court in a challenge by a number of those involved in the murder of Garda Jerry McCabe and the wounding of his colleague in a botched robbery in Adare in 1996. As Chief Justice Keane confirmed 'It would have been open to the Oireachtas to have provided a statutory definition of "qualifying prisoners" ...the fact that they did not do so and that it is for the Minister, and the Minister alone, to determine who should be treated as "qualifying prisoners" ... It is, moreover, a discretion which, when exercised, is a preliminary to the possible exercise by him or the government of the power of release constitutionally vested in them. The power to release itself, whether exercised on what might be called conventional grounds of a compassionate or humanitarian nature or for purely political considerations as in the case of releases effected for the purpose of giving effect to the Good Friday Agreement, is a quintessentially executive function and one which is discharged by them.' O’Neill \& Anor v. Governor of Castlerea Prison \& Ors IESC 7 (29 January 2004) [2004] 1 IR 298. 


\begin{tabular}{|c|c|c|}
\hline & \multicolumn{2}{|c|}{$\begin{array}{l}\text { - In addition, given that a key principle in the design of the } \\
\text { ICIR is that either state or non-state actors should do so } \\
\text { voluntarily, some may feel that an incentivised engagement } \\
\text { for those who have been convicted of conflict-related } \\
\text { offences could undermine the broader credibility of the ICIR } \\
\text { as a victim-centred information recovery mechanism. }\end{array}$} \\
\hline $\begin{array}{l}\text { Compatibility } \\
\text { with human } \\
\text { rights } \\
\text { obligations }\end{array}$ & $\begin{array}{l}\text { - The SHA is specifically designed to be } \\
\text { compliant with all human rights obligations } \\
\text { (in particular Article } 2 \text { of the ECHR) which } \\
\text { guarantees the right to an independent, prompt, } \\
\text { effective, and transparent investigation which } \\
\text { is capable of leading to a prosecution. } \\
\text { - This proposal would see the SHA implemented with } \\
\text { an Article } 2 \text { compliant investigation, the decision } \\
\text { being taken on whether or not to prosecute by the } \\
\text { DPP and the rule of law being upheld with a judge } \\
\text { (in Diplock proceedings) determining innocence or } \\
\text { guilt or a judge and jury in a normal criminal trial. } \\
\text { - There are no binding international legal standards } \\
\text { on the length of prison sentences to be served for } \\
\text { conflict-related offences. However, any attempt } \\
\text { to reduce jail time to zero for members of the } \\
\text { security forces only would be open to challenge } \\
\text { on the basis of the procedural obligations of } \\
\text { Article } 2 \text { ECHR, when read with Article } 14 \text {, in the } \\
\text { context of differential treatment in the capability } \\
\text { of punishment of offenders. This is the case } \\
\text { insofar as even if there would be no breach of } \\
\text { the procedural requirements of Article } 2 \text { per se } \\
\text { in relation to sentencing without differential } \\
\text { treatment, a different regime for the security } \\
\text { forces, would engage Article } 14 \text { compliance. }{ }^{98}\end{array}$ & \\
\hline $\begin{array}{l}\text { Compatibility } \\
\text { with GFA }\end{array}$ & $\begin{array}{l}\text { - The Good Friday Agreement provides for the } \\
\text { incorporation of the ECHR with which this } \\
\text { proposal compatible. In addition, the mechanism } \\
\text { envisaged for the early release of prisoners } \\
\text { (the Sentence Review Commission) was } \\
\text { established by the Good Friday Agreement. }\end{array}$ & \\
\hline
\end{tabular}

98 Article 14 is an accessory right (sometimes called a parasitic right) and can only be argued when another Convention right is in play; this is often called the ambit requirement. However, it is not a requirement that the substantive ECHR right have been violated in itself. 
- The compatibility of the SHA legislation with the original SHA would be dependent on whether the final specific provisions therein represent a 'good faith' implementation of that Agreement.

- The SHA is silent on the question of the length of time to be served after a person has been convicted. It might, however, be implied that in agreeing to retain a prosecution option as part of the broader legacy package of measures, the signatories

Compatibility with SHA did so on the assumption that those convicted would serve at least two years imprisonment.

- Given the emphasis on the importance of information recovery and reconciliation within the SHA, it would certainly be easier to argue that a trade-off of reduced prison time from two years to zero in exchange for increased information recovery (via the ICIR) was more in keeping with the spirit of the SHA that other mechanisms which remove prison time without any 'value added' regarding information recovery. 


\section{Proposal 11:}

\section{Implement the SHA, Reduce Conflict-Related Imprisonment to Zero with no ICIR Cooperation Requilrement}

\begin{tabular}{|c|c|}
\hline $\begin{array}{l}\text { Overview of } \\
\text { Proposal }\end{array}$ & $\begin{array}{l}\text { Implement the SHA, Reduction of Conflict- } \\
\text { Related Imprisonment to Zero with No } \\
\text { ICIR Cooperation Requirement }\end{array}$ \\
\hline \multirow[t]{2}{*}{$\begin{array}{l}\text { Source of } \\
\text { proposal }\end{array}$} & $\begin{array}{l}\text { In compiling this report, it became apparent that the power } \\
\text { already exists for the Secretary of State for Northern Ireland } \\
\text { to vary the two-year maximum imprisonment sentence for } \\
\text { conflict-related offences. In order to inform public debate, } \\
\text { we have therefore included this option i.e. implementing the } \\
\text { SHA and reducing all conflict-related prison sentences to } \\
\text { zero - without any conditional engagement with the ICIR. }\end{array}$ \\
\hline & $\begin{array}{l}\text { - The Good Friday Agreement committed both governments to } \\
\text { establishing a review process designed to set prospective release } \\
\text { dates for all qualifying prisoners. }{ }^{99} \text { It further stipulated that } \\
\text { should the circumstances allow it, any qualifying prisoners who } \\
\text { remained in custody two years after the commencement of the } \\
\text { scheme would be released at that point. } \\
\text { - Section 10(7) of the Northern Ireland Sentences Act which enacted } \\
\text { that commitment stipulated that any prisoner who applied to } \\
\text { the early release scheme cannot be released 'before he has served } \\
\text { two years of the sentence to which the declaration relates'. The } \\
\text { declaration in this instance is a formal finding that the prisoner is } \\
\text { eligible for early release. Given the commitment in the GFA that } \\
\text { all prisoners would eligible for release within two years of the } \\
\text { scheme, and the provisions of section } 10(7) \text {, this was subsequently } \\
\text { interpreted to mean that any person convicted after } 1998 \text { for pre- } \\
\text { 1998 conflict-related offences would serve a maximum of two years. } \\
\text { - However, section 10(8) stipulated that 'the Secretary of State } \\
\text { may by order amend subsections 4-7.' This means that the } \\
\text { two-year time frame can already be reduced to zero by an } \\
\text { order in council rather than requiring primary legislation. }\end{array}$ \\
\hline
\end{tabular}

99 A qualifying prisoner is a person convicted of a qualifying offence (i.e. a scheduled offence committed before April 1998); not a supporter of a specified organisation (e.g. an anti-peace process group); if released immediately would not be likely to become a supporter of such a group or to become involved in acts of terrorism connected to the affairs of Northern Ireland; if released immediately would not be a danger to the public (Section 3, 3-7) Northern Ireland Sentences Act 1998.

100 Belfast/Good Friday Agreement 1998, Prisoners' section, paragraph 3. 


\begin{tabular}{|c|c|}
\hline $\begin{array}{l}\text { Compatibility } \\
\text { with human } \\
\text { rights } \\
\text { obligations }\end{array}$ & $\begin{array}{l}\text { - This option is premised upon implementing the } \\
\text { SHA. As noted above, the SHA is specifically } \\
\text { designed to be compliant with all human rights } \\
\text { obligations (in particular Article } 2 \text { of the ECHR) } \\
\text { which guarantees the right to an independent, } \\
\text { prompt, effective, and transparent investigation } \\
\text { which is capable of leading to a prosecution. } \\
\text { - This proposal would see the SHA implemented with } \\
\text { an Article } 2 \text { compliant investigation, the decision } \\
\text { being taken on whether or not to prosecute by the } \\
\text { DPP and the rule of law being upheld with a judge } \\
\text { (in Diplock proceedings) determining innocence or } \\
\text { guilt or a judge and jury in a normal criminal trial. } \\
\text { - As with the preceding option, there are no binding } \\
\text { international legal standards on the length of } \\
\text { prison sentences to be served for conflict-related } \\
\text { offences. However, any attempt to reduce jail } \\
\text { time to zero for members of the security forces } \\
\text { only would be open to challenge on the basis } \\
\text { of the procedural obligations of Article } 2 \text { ECHR, } \\
\text { when read with Article } 14 \text { on non-discrimination, } \\
\text { in the context of differential treatment in the } \\
\text { capability of punishment of offenders. This is } \\
\text { the case insofar as even if there would be no } \\
\text { breach of procedural requirements of Article } 2 \text { per } \\
\text { se in relation to sentencing without differential } \\
\text { treatment, a different regime for the security } \\
\text { forces, would engage Article } 14 \text { compliance. }\end{array}$ \\
\hline
\end{tabular}

101 Article 14 is an accessory right (sometimes called a parasitic right) and can only be argued when another Convention right is in play; this is often called the ambit requirement. However it is not a requirement that the substantive ECHR right have been violated in itself. 


\begin{tabular}{|c|c|}
\hline $\begin{array}{l}\text { Compatibility } \\
\text { with GFA }\end{array}$ & $\begin{array}{l}\text { - The Good Friday Agreement provides for } \\
\text { the incorporation of the ECHR with which } \\
\text { this proposal is compatible. In addition, the } \\
\text { mechanism envisaged for the early release of } \\
\text { prisoners (the Sentence Review Commission) was } \\
\text { established by the Good Friday Agreement. } \\
\text { - As noted above, the GFA stipulates that all } \\
\text { prisoners will be released within two years } \\
\text { of the commencement of the early release } \\
\text { scheme. This provision was clearly intended } \\
\text { to reassure those who had advocated for } \\
\text { early release during the negotiations that the } \\
\text { process would not be unnecessarily extended } \\
\text { in order to keep prisoners incarcerated. } \\
\text { - While section 10(7) of the Northern Ireland } \\
\text { Sentences Act requires that prisoners serve at least } \\
\text { two years, the fact that the power to alter that two } \\
\text { years was contained in the same GFA enabling } \\
\text { legislation would suggest that the UK government } \\
\text { at the time envisaged the possibility of altering the } \\
\text { two year minimum threshold at some juncture. }\end{array}$ \\
\hline $\begin{array}{l}\text { Compatibility } \\
\text { with SHA }\end{array}$ & $\begin{array}{l}\text { - The compatibility of the SHA legislation with } \\
\text { the original SHA will depend whether the final } \\
\text { specific provisions therein represent a 'good } \\
\text { faith' implementation of that Agreement. } \\
\text { - As noted above the SHA is silent on the } \\
\text { question of the length of time to be served } \\
\text { after a person has been convicted. However, } \\
\text { it might be assumed that in agreeing to retain } \\
\text { a prosecution option as part of the broader } \\
\text { legacy package of measures, the signatories } \\
\text { did so on the assumption that those convicted } \\
\text { would serve at least two years imprisonment. } \\
\text { - Given the emphasis on the importance of } \\
\text { information recovery and reconciliation within the } \\
\text { SHA, it would certainly be easier to argue that a } \\
\text { trade-off of reduced prison time to zero in exchange } \\
\text { for increased information recovery (via the ICIR) } \\
\text { was more in keeping with the spirit of the SHA that } \\
\text { a mechanism that removes prison time without } \\
\text { any 'value added' regarding information recovery. }\end{array}$ \\
\hline
\end{tabular}




\section{Conclusion}

As noted above, our purpose in producing this report is to provide clear and accessible legal and policy analysis to help readers make up their own mind on these complex and sensitive matters.

As detailed above, we have benchmarked all of the significant proposals placed in the public domain on prosecutions, imprisonment and dealing with the past in the last decade against binding international and domestic human rights obligations, compatibility with the Good Friday Agreement and compatibility with the Stormont House Agreement. The rationale for the first two benchmarks is self-explanatory. One cannot imagine that either the UK or Irish governments or indeed the Northern Ireland Executive would countenance any legacy process that was incompatible with the rule of law. With regard to the Good Friday Agreement, it is important to note that it is not just an Agreement between its signatories, but also an international treaty between its co-guarantors - the British and Irish governments. Moreover, it remains the cornerstone of the peace process.

With regard to the SHA, we have consistently argued that the best way to address the legacy of the past in Northern Ireland is to implement the SHA mechanisms in good faith, maximise their independence and appoint good staff to ensure that they deliver on the promises made to victims. That remains our position. With three distinct mechanisms (HIU, ICIR, OHA) conducting different tasks and another one (the IRG) over-seeing broader themes, archives and information recovery, the SHA is undoubtedly complex. Nonetheless, it was concluded after extensive negotiations in 2013 and 2014 - a full 16 years after the Good Friday Agreement - and it remains the closest we have come to reaching consensus on dealing with the legacy of the conflict. Any effort by either of the two governments or any of the Northern Ireland parties involved in the SHA negotiations to depart from its terms is highly unlikely to secure the agreement of the other actors.

The ensuing result would almost inevitably be a failure to deliver on the long-promised commitments to victims and survivors and a return to the status quo ante 'piecemeal' approach to the past, with all of its manifest failings including the risks associated with the policing settlement in Northern Ireland and the inevitable political pressures placed on the functioning of the Executive..$^{102}$

As noted above, the principles underpinning the SHA were designed to ensure that it delivers justice and information recovery in ways that are human rights compliant, proportionate, transparent, fair and equitable, promote reconciliation and acknowledge and address the suffering of victims and survivors. With regard to the latter principle, the SHA contains a provision, which has to date, received comparatively little attention. It states, 'in the 
context of the work of the IRG, the UK and Irish Governments will consider statements of acknowledgement and would expect others to do the same. ${ }^{103}$

We would thus urge that, in addition to the benchmarking exercise above with regard to dealing with the past in Northern Ireland, the role of acknowledgement should not be lost in finally addressing the legacy of the Northern Ireland conflict. Significant statements that have been made to date include the apology in 2010 by former Prime Minister David Cameron in the wake of Saville report into Bloody Sunday; the Combined Loyalist Military Command statement in 1994; and the IRA statement on the 30th anniversary of the Bloody Friday bombings in 2002. These statements of acknowledgement or apology are undoubtedly important features of addressing past harms. ${ }^{104}$

In a survey of 1,000 members of the public in Northern Ireland and the Republic carried out by Queen's University, $69 \%$ of respondents across the island as a whole $72 \%$ in Northern Ireland) considered apologies as an important part of dealing with the legacy of the conflict. 105

Effective apologies or statements of acknowledgement are explicitly not a 'soft alternative' to human-rights compliant justice, information recovery, reparations and other means of addressing past violence. Rather they are envisaged as complementary to such measures - offering the opportunity to finally draw a line under a violent past, promote reconciliation and commit to the principle of non-recurrence.

103 Stormont House Agreement (2014) Paragraph 53. The predecessor to the SHA, the Hass O'Sullivan (2013) Proposed Agreement Among The Parties Of The Northern Ireland Executive on Parades, Select Commemorations, And Related Protests; Flags and Emblems; and Contending With The Past (p.23-24) 'We encourage individuals, organisations and the national governments would work together on issues related to language, timing and other matters before issuing public statements of acknowledgement in ways that contribute positively to healing and reconciliation. We commit to working among ourselves, with organisations in Northern Ireland, and with the governments of the United Kingdom and Ireland, to build an environment in which full and constructive acknowledgements, whether individual or corporate, can be expressed and can build on one another. This process should aim to be as inclusive and as complete as possible, involving all those who played roles in the conflict. We hope and anticipate that statements of acknowledgment by leaders will encourage others to make similar statements or gestures of acknowledgment, including participating in the retrieval of information as outlined below.

104 K. McEvoy and A. Bryson Apologies Abuses and Dealing with the Past. KESS Seminar Stormont Great Hall, July 2018. https://apologies-abuses-past.org.uk/outputs/reports/ For a general template as to how to maximise the effectiveness of apologies or statements of acknowledgement in post-conflict context see K. McEvoy, A. Bryson and C. Plaznek (2019) Apologies in Transitional Justice. Report prepared for the United Nations Special Rapporteur on the Promotion of Truth, Justice, Reparations and Guarantees of Non-recurrence. Available https://apologies-abuses-past.org.uk/.

105 S. Maruna et al (2020) Dealing with the Past in Ireland: Results from a Public Survey. Available https://apologies-abusespast.org.uk/ 


\title{
PROSECUTIONS, IMPRISONMENT AND THE STORMONT HOUSE AGREEMENT
}

\author{
A Critical Analysis of \\ Proposals on Dealing with \\ the Past in Northern Ireland
}

Kieran McEvoy, Daniel Holder, Louise Mallinder, Anna Bryson, Brian Gormally \& Gemma McKeown

April 2020

www.dealingwiththepastni.com 